\title{
Biological Significance of the Protein Changes Occurring in the Cerebrospinal Fluid of Alzheimer's Disease Patients: Getting Clues from Proteomic Studies
}

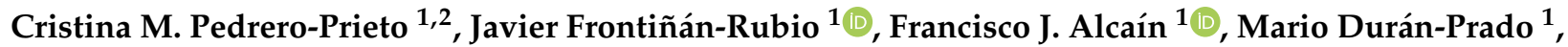 \\ Juan R. Peinado ${ }^{1, *(\mathbb{D})}$ and Yoana Rabanal-Ruiz ${ }^{1, *}$
}

Citation: Pedrero-Prieto, C.M.; Frontiñán-Rubio, J.; Alcaín, F.J.; Durán-Prado, M.; Peinado, J.R.; Rabanal-Ruiz, Y. Biological Significance of the Protein Changes Occurring in the Cerebrospinal Fluid of Alzheimer's Disease Patients: Getting Clues from Proteomic Studies. Diagnostics 2021, 11, 1655. https:// doi.org/10.3390/diagnostics11091655

Academic Editor: Panteleimon Giannakopoulos

Received: 30 June 2021

Accepted: 26 August 2021

Published: 9 September 2021

Publisher's Note: MDPI stays neutra with regard to jurisdictional claims in published maps and institutional affiliations.

Copyright: (c) 2021 by the authors. Licensee MDPI, Basel, Switzerland. This article is an open access article distributed under the terms and conditions of the Creative Commons Attribution (CC BY) license (https:/ / creativecommons.org/licenses/by/ $4.0 /)$.
1 Department of Medical Sciences, Ciudad Real Medical School, Oxidative Stress and Neurodegeneration Group, CRIB, University of Castilla-La Mancha (UCLM), Paseo de Moledores SN, 13071 Ciudad Real, Spain; CristinaM.Pedrero@uclm.es (C.M.P.-P.); Javier.Frontinan@uclm.es (J.F.-R.); franciscoj.alcain@uclm.es (F.J.A.); Mario.duran@uclm.es (M.D.-P.)

2 Neuroplasticity and Neurodegeneration Laboratory, Ciudad Real Medical School, CRIB, University of Castilla-La Mancha (UCLM), 13005 Ciudad Real, Spain

* Correspondence: Juanramon.peinado@uclm.es (J.R.P.); Yoana.Rabanal@uclm.es (Y.R.-R.)

\begin{abstract}
The fact that cerebrospinal fluid (CSF) deeply irrigates the brain together with the relative simplicity of sample extraction from patients make this biological fluid the best target for biomarker discovery in neurodegenerative diseases. During the last decade, biomarker discovery has been especially fruitful for the identification new proteins that appear in the CSF of Alzheimer's disease (AD) patients together with amyloid- $\beta$ (A $\beta 42)$, total tau ( $\mathrm{T}-\mathrm{tau})$, and phosphorylated tau (P-tau). Thus, several proteins have been already stablished as important biomarkers, due to an increase (i.e., CHI3L1) or a decrease (i.e., VGF) in AD patients' CSF. Notwithstanding this, only a deep analysis of a database generated with all the changes observed in CSF across multiple proteomic studies, and especially those using state-of-the-art methodologies, may expose those components or metabolic pathways disrupted at different levels in AD. Deep comparative analysis of all the upand down-regulated proteins across these studies revealed that $66 \%$ of the most consistent protein changes in CSF correspond to intracellular proteins. Interestingly, processes such as those associated to glucose metabolism or RXR signaling appeared inversely represented in CSF from AD patients in a significant manner. Herein, we discuss whether certain cellular processes constitute accurate indicators of AD progression by examining CSF. Furthermore, we uncover new CSF AD markers, such as ITAM, PTPRZ or CXL16, identified by this study.
\end{abstract}

Keywords: Alzheimer's disease; proteomics; cerebrospinal fluid; CSF; biomarkers

\section{Introduction}

The cerebrospinal fluid (CSF) circulates around the brain and spinal cord, thus, constituting the most valuable biofluid for the identification of biomolecules associated with different brain pathologies, especially neurodegenerative diseases [1]. The number of studies aimed at understanding the composition in biomolecules with different origins in CSF and how they change during the development of brain associated diseases has increased strongly during the last decade [2,3]. Moreover, a basic search through the literature using MEDLINE (via PubMed) using the terms proteomics, CSF, and different brain pathologies reveals the significant increase that these studies have experienced during the last years (Figure 1), mostly due to the development of state-of-the-art technologies that have expanded the number of proteins and peptides identified in this biofluid from hundreds to thousands. 


\section{Evolution of research in the last 3 years}

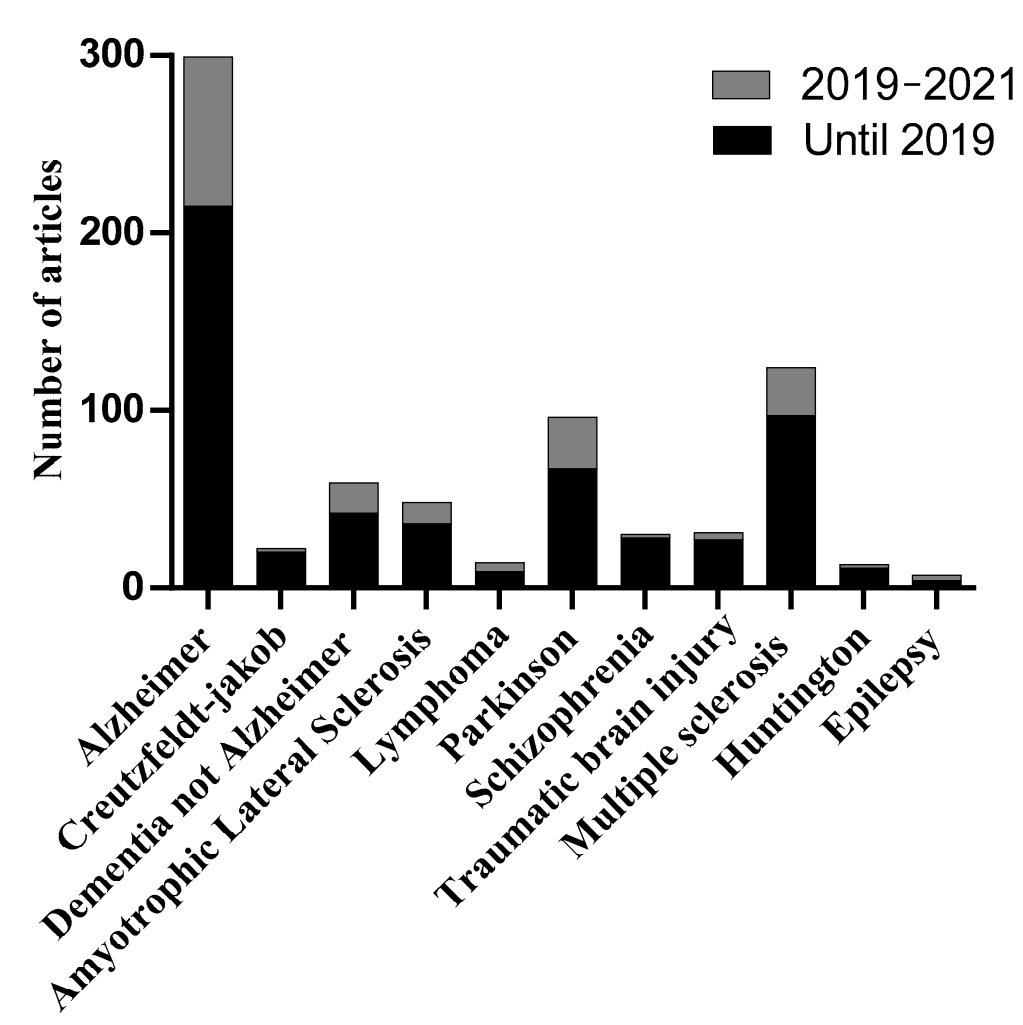

\section{Diseases}

Figure 1. Articles published with the subject "proteomics, cerebrospinal fluid and different brain pathologies". (Publications until June 2021). Articles published during the last three years are shown in grey.

Specifically, in Alzheimer's disease (AD), the most widespread neurodegenerative disease, more than 300 articles have addressed the search for CSF protein markers (Figure 1). The number of proteomic studies has increased during the last years and almost 100 of them have appeared since 2019. Several of these studies propose specific reliable biomarkers of $\mathrm{AD}$ in CSF [4] and several reviews have gathered information from them to demonstrate the consistent role for amyloid- $\beta$ (A $\beta 1-42)$, total tau (T-tau), and phosphorylated tau ( $\mathrm{P}-$ tau) $[5,6]$, as well as other proteins such as VGF nerve growth factor inducible (decreased in $\mathrm{AD}$ ) or CH3L1 (increased in AD) [7,8], and certain family of proteins, such as granins or pentraxins, as reliable hallmarks of $\mathrm{AD}$ relevant for diagnosis $[6,9,10]$.

The recent exponential increase of new proposed candidates as protein biomarkers of $\mathrm{AD}$ in CSF evidence the necessity of a deeper analysis of the most consistent findings across studies. Therefore, we have compiled the most recent data from proteomic studies into a database in order to perform an analysis that takes into account the biological function of each protein, considering their role in the cell and their interrelationships. This study allowed us to identify underlying biological mechanisms in AD that appear reflected in CSF, as well as highlight emerging CSF biomarkers of AD.

\section{Materials and Methods}

The search for articles was limited between January 2012 and June 2021 (i.e., the last decade), and carried out using the PubMed and Google Scholar databases. The filter "humans" was applied and the following keywords were used for the search "cerebrospinal fluid" and/or "CSF", "Alzheimer's", "biomarker", "MS/MS", "proteomics" and "mass 
spectrometry". Notwithstanding this, our search retrieved several review articles and studies focused exclusively on unique proteins that were not included in the analysis.

A deeper analysis was performed in those articles to select AD CSF studies containing both quantitative information and a clear statistical analysis that corroborated their findings. Only those studies that compared healthy controls vs. AD were included, discarding the articles that compared samples of different diseases without including healthy individuals as controls. Following these criteria, a total of 30 articles were selected to generate a database (Supplemental Table S1). Supplemental Table S1 lists the titles of each of the selected articles, the proteomic approaches used, and the number of proteins identified in each article with up- or down- expression in AD. To generate our database, proteins that showed consistent direction of change across different studies (proteins that appeared in at least two studies following the same direction) were considered for the analysis and classified according to their biological function (Table 1) and the information obtained on July 2021 for each protein in Uniprot and IPA (QIAGEN Inc., Hilden, Germany) databases. Network analysis and relevant metabolic pathways were explored using IPA, String (https: / / string-db.org, accessed on 5 July 2021) and Reactome (https:/ / reactome.org, accessed on 5 July 2021). Reactome $p$-values are corrected for the multiple testing (BenjaminiHochberg procedure) that arises from evaluating the submitted list of identifiers against every pathway [9]. For these analyses, it was considered whether the proteins were upor down-regulated in the context of $\mathrm{AD}$, which was crucial for the interpretation and organization of the information discussed in this review. Those proteins that showed the most consistent changes were explored in order to obtain accurate information regarding their biological function and its potential correlation with AD pathology. Especial attention was given to those proteins that constitute potentially novel biomarkers of AD.

Table 1. Proteins identified in CSF proteomic studies from Alzheimer's patients that appear with similar direction of change in two or more articles. This analysis has been performed with the literature published during the last 10 years (see Materials and Methods).

\begin{tabular}{|c|c|c|c|}
\hline Uniprot (Human) & Description & Identified in N Articles & References \\
\hline \multicolumn{4}{|c|}{ GLUCOSE/PYRUVATE METABOLISM } \\
\hline ALDOA & aldolase, fructose-bisphosphate A & 6 (up)* & [10-15] \\
\hline ALDOC & aldolase, fructose-bisphosphate C & 2 (up) & {$[12,13]$} \\
\hline ENOA & enolase 1 & 2 (up) & {$[12,13]$} \\
\hline G6PI & glucose-6-phosphate isomerase & 2 (up) & {$[12,13]$} \\
\hline LDHA & lactate dehydrogenase $\mathrm{A}$ & 3 (up) & {$[10,12,13]$} \\
\hline LDHB & lactate dehydrogenase B & 2 (up) & {$[16,17]$} \\
\hline MDHC & malate dehydrogenase 1 & 5 (up) * & {$[10,12,14,18,19]$} \\
\hline PGAM1 & phosphoglycerate mutase 1 & 2 (up) & {$[10,12]$} \\
\hline KPYM & pyruvate kinase M1/2 & 7 (up) & {$[11-16,20]$} \\
\hline TPIS & triosephosphate isomerase 1 & 2 (up) & {$[12,17]$} \\
\hline \multicolumn{4}{|c|}{ RXR SIGNALING (LXR/RXR ACTIVATION PATHWAY) } \\
\hline FETUA & alpha 2-HS glycoprotein & 2 (down) & {$[12,21]$} \\
\hline ALBU \# & albumin & 3 (down)* & {$[17,21,22]$} \\
\hline AMBP & alpha-1-microglobulin/bikunin precursor & 3 (down) & {$[12,17,23]$} \\
\hline APOA1 $\$$ & apolipoprotein $\mathrm{A} 1$ & 4 (down) & {$[17,22-24]$} \\
\hline APOC2 & apolipoprotein C2 & 2 (down) & {$[17,20]$} \\
\hline APOL1 & apolipoprotein L1 & 2 (down) & {$[11,12]$} \\
\hline C1QB & complement $\mathrm{C} 1 \mathrm{q}$ B chain & 3 (down) & {$[10,17,25]$} \\
\hline CLUS $^{\$}$ & clusterin & 4 (up) & {$[19,22,26,27]$} \\
\hline CERU \# & ceruloplasmin & 4 (down) * & {$[11-13,17]$} \\
\hline $\mathrm{KNG}^{\Delta}{ }^{\Delta}$ & kininogen 1 & 3 (down) & {$[12,13,17]$} \\
\hline LDLR & low density lipoprotein receptor & 3 (down) & {$[12,20,28]$} \\
\hline RET4 & retinol binding protein 4 & 2 (down) & {$[12,17]$} \\
\hline
\end{tabular}


Table 1. Cont.

\begin{tabular}{|c|c|c|c|}
\hline Uniprot (Human) & Description & Identified in N Articles & References \\
\hline $\mathrm{SODM}^{\Delta}$ & superoxide dismutase 2 & 2 (up) & {$[12,13]$} \\
\hline TR11B & TNF receptor superfamily member $11 b$ & 2 (up) & {$[12,28]$} \\
\hline \multicolumn{4}{|c|}{ NEURONAL FUNCTION/SYNAPTOGENESIS } \\
\hline ACES & acetylcholinesterase (Cartwright blood group) & 2 (up) & {$[10,12]$} \\
\hline APLP1 $\$$ & amyloid beta precursor like protein 1 & 3 (down)* & {$[17,21,26]$} \\
\hline APLP2 $\$$ & amyloid beta precursor like protein 2 & 3 (up) & {$[15,17,26]$} \\
\hline $\mathrm{A} 4^{\$}$ & amyloid beta precursor protein & $3($ down $) *$ & {$[17,26,29]$} \\
\hline KCC2G & $\begin{array}{l}\text { calcium/calmodulin dependent protein kinase II } \\
\text { gamma }\end{array}$ & 2 (up) & {$[12,13]$} \\
\hline $\mathrm{CSTN}^{\varepsilon}$ & calsyntenin 3 & 3 (down)* & {$[15,17]$} \\
\hline CPLX2 & complexin 2 & 2 (up) & {$[10,12]$} \\
\hline EPHA7 & EPH receptor A7 & 2 (down) & {$[10,12]$} \\
\hline NEUM & growth associated protein 43 & 4 (up) & {$[11,12,14,30]$} \\
\hline GDIA & GDP dissociation inhibitor 1 & 2 (up) & {$[10,12]$} \\
\hline MANF & mesencephalic astrocyte derived neurotrophic factor & 2 (up) & {$[12,20]$} \\
\hline MARCS & myristoylated alanine rich protein kinase $C$ substrate & 3 (up) & {$[10,12,14]$} \\
\hline $\mathrm{MT}^{\Delta}$ & metallothionein 3 & 2 (down) & {$[20,21]$} \\
\hline NFL & neurofilament light & 2 (up) & {$[12,20]$} \\
\hline NFM & neurofilament medium & 3 (up) & {$[11,12,26]$} \\
\hline NPTX1 & neuronal pentraxin 1 & 3 (down) & {$[25,31,32]$} \\
\hline NPTX2 & neuronal pentraxin 2 & 4 (down) & {$[12,20,25,33]$} \\
\hline NPTXR & neuronal pentraxin receptor & 5 (down) & {$[11,12,25,33,34]$} \\
\hline NEUG & neurogranin & 4 (up) & {$[12,20,30,33]$} \\
\hline NRX1A & neurexin 1 & $4($ down $) *$ & {$[12,21,25,31]$} \\
\hline NRX2A & neurexin 2 & 3 (down) & {$[12,20,25]$} \\
\hline NRX3B & neurexin 3 & 2 (down) & {$[20,31]$} \\
\hline PACN1 & protein kinase $\mathrm{C}$ and casein $\mathrm{k}$. substrate in neurons 1 & 2 (up) & {$[11,12]$} \\
\hline PCLO & piccolo presynaptic cytomatrix protein & 2 (up) & {$[12,26]$} \\
\hline RP3A & rabphilin $3 \mathrm{~A}$ & 2 (up) & {$[12,20]$} \\
\hline RTN4 & reticulon 4 & 2 (up) & {$[12,26]$} \\
\hline SYUG & synuclein gamma & 2 (up) & {$[10,12]$} \\
\hline SYN1 & synapsin I & 2 (up) & {$[11,12]$} \\
\hline TKNK & tachykinin precursor 3 & 2 (down) & {$[21,26]$} \\
\hline TREM $2 \$, \varepsilon$ & triggering receptor expressed on myeloid cells 2 & 2 (up) & {$[12,19]$} \\
\hline \multicolumn{4}{|c|}{ CELL ADHESION/EXTRACELLULAR MATRIX } \\
\hline C1QT1 & $\mathrm{C} 1 \mathrm{q}$ and $\mathrm{TNF}$ related 1 & 2 (down) & {$[11,12]$} \\
\hline C1QT5 & $\mathrm{C} 1 \mathrm{q}$ and TNF related 5 & 2 (up) & {$[12,35]$} \\
\hline $\mathrm{CD}^{\mathrm{\varepsilon}}{ }^{\varepsilon}$ & CD99 molecule (Xg blood group) & 2 (up) & {$[15,26]$} \\
\hline NCHL1 & cell adhesion molecule L1 like & 2 (down) & {$[17,32]$} \\
\hline FBLN3 & EGF containing fibulin extracellular matrix protein 1 & 2 (down) & {$[17,20]$} \\
\hline FBLN1 & fibulin 1 & 3 (down) & {$[10,13,17]$} \\
\hline ITAM & integrin subunit alpha $\mathrm{M}$ & 3 (up) & {$[11,12,20]$} \\
\hline MUC18 & melanoma cell adhesion molecule & 4 (down) & {$[15,17,25,32]$} \\
\hline $\operatorname{MMP2} \Delta$ & matrix metallopeptidase 2 & 2 (down) & {$[12,28]$} \\
\hline NID2 & nidogen 2 & 2 (down) & {$[12,13]$} \\
\hline PGRP2 & peptidoglycan recognition protein 2 & 2 (down) & {$[11,12,17]$} \\
\hline SMOC1 & SPARC related modular calcium binding 1 & 7 (up)* & {$[10-15,35]$} \\
\hline SMOC2 & SPARC related modular calcium binding 2 & 2 (up) & {$[12,28]$} \\
\hline SPRC & secreted protein acidic and cysteine rich & 3 (up) & {$[17,24,26]$} \\
\hline TICN1 & $\begin{array}{c}\text { SPARC (osteonectin), cwcv and kazal like domains } \\
\text { proteoglycan } 1\end{array}$ & $3($ down $) *$ & {$[10,17,21]$} \\
\hline SPON1 & spondin 1 & 3 (up) & {$[12,15,26]$} \\
\hline
\end{tabular}


Table 1. Cont.

\begin{tabular}{|c|c|c|c|}
\hline Uniprot (Human) & Description & Identified in N Articles & References \\
\hline \multicolumn{4}{|c|}{ 14-3-3 PROTEINS } \\
\hline 1433B & $\begin{array}{l}\text { tyrosine 3-monooxygenase/tryptophan } \\
\text { 5-monooxygenase activation protein beta }\end{array}$ & 3 (up) & {$[11,12,20]$} \\
\hline $1433 \mathrm{E}$ & $\begin{array}{l}\text { tyrosine 3-monooxygenase/tryptophan } \\
\text { 5-monooxygenase activation protein epsilon }\end{array}$ & 5 (up) & {$[10-12,33,36]$} \\
\hline $1433 G$ & $\begin{array}{l}\text { tyrosine 3-monooxygenase/tryptophan } \\
\text { 5-monooxygenase activation protein gamma }\end{array}$ & 4 (up) & {$[10,12,13,20]$} \\
\hline $1433 Z$ & $\begin{array}{l}\text { tyrosine 3-monooxygenase/tryptophan } \\
\text { 5-monooxygenase activation protein zeta }\end{array}$ & 5 (up) & {$[10-13,33]$} \\
\hline \multicolumn{4}{|c|}{ CYTOKINE (C)/HORMONAL (H) ACTIVITIES } \\
\hline CCKN & cholecystokinin $(\mathrm{H})$ & 2 (up) & {$[13,26]$} \\
\hline CMGA & chromogranin A $(\mathrm{H})$ & 4 (down) * & {$[21,31,34,36]$} \\
\hline SCG1 & chromogranin B $(\mathrm{H})$ & 3 (down)* & {$[12,17,21]$} \\
\hline CXL16 & C-X-C motif chemokine ligand $16(\mathrm{C})$ & 3 (up) & {$[10,20,26]$} \\
\hline MIF & macrophage migration inhibitory factor (C) & 2 (up) & {$[12,13]$} \\
\hline SCG2 & secretogranin II $(\mathrm{H})$ & 6 (down) * & {$[12,17,20,21,26,31]$} \\
\hline SCG3 & secretogranin III $(\mathrm{H})$ & 3 (down)* & {$[17,21,26]$} \\
\hline OSTP & secreted phosphoprotein 1 (C) & 7 (up) \& & {$[11-13,15,18,19,26]$} \\
\hline SMS & Somatostatin $(\mathrm{H})$ & 3 (down) & {$[12,20,26]$} \\
\hline VGF & VGF nerve growth factor inducible $(\mathrm{H})$ & $11($ down $) *$ & $\begin{array}{c}{[11,12,21,24,26,31,} \\
34,36-38]\end{array}$ \\
\hline VIP & vasoactive intestinal peptide $(\mathrm{H})$ & 2 (down) & {$[12,20]$} \\
\hline \multicolumn{4}{|c|}{ CYTOSKELETAL PROTEINS } \\
\hline GELS $\$$ & gelsolin & 3 (down) & {$[11,12,20]$} \\
\hline K22E & keratin 2 & 2 (up) & {$[11,12]$} \\
\hline K1C9 & keratin 9 & 2 (up) & {$[20,29]$} \\
\hline MAP1B & microtubule associated protein $1 \mathrm{~B}$ & 2 (up) & {$[11,12]$} \\
\hline MTAP2 & microtubule associated protein 2 & 3 (up) & {$[11,12,20]$} \\
\hline TAU & microtubule associated protein tau & 4 (up) & {$[11-13,20]$} \\
\hline STMN1 & stathmin 1 & 2 (up) & {$[11,12]$} \\
\hline \multicolumn{4}{|c|}{ REDOX BALANCE/DETOXIFICATION PROCESSES } \\
\hline AATM & glutamic-oxaloacetic transaminase 2 & 2 (up) & {$[12,13]$} \\
\hline GSHR & glutathione-disulfide reductase & 2 (up) & {$[12,13]$} \\
\hline GSTO1 & glutathione S-transferase omega 1 & 2 (up) & {$[12,13]$} \\
\hline PARK7 & Parkinsonism associated deglycase & 2 (up) & {$[12,13]$} \\
\hline PPIA & peptidylprolyl isomerase A & 2 (up) & {$[12,13]$} \\
\hline PPIB & peptidylprolyl isomerase B & 2 (down) & {$[10,17]$} \\
\hline $\mathrm{SODE}^{\#, \varepsilon}$ & superoxide dismutase 3 & 2 (down) & {$[10,15]$} \\
\hline TRXR2 & thioredoxin reductase 2 & 2 (up) & {$[12,20]$} \\
\hline \multicolumn{4}{|c|}{ SIGNAL TRANSDUCTION } \\
\hline IGF1R & insulin like growth factor 1 receptor & 2 (up) & {$[12,20]$} \\
\hline $\mathrm{IBP}^{\varepsilon}$ & insulin like growth factor binding protein 6 & 2 (down) & {$[12,15]$} \\
\hline IMPA1 & inositol monophosphatase 1 & 2 (up) & {$[12,13]$} \\
\hline PEBP1 & phosphatidylethanolamine binding protein 1 & 2 (up) & {$[10,12]$} \\
\hline PTPRZ & protein tyrosine phosphatase receptor type $\mathrm{Z1}$ & 3 (up) & {$[12,17,26]$} \\
\hline SH3L3 & SH3 domain binding glutamate rich protein like & 2 (up) & {$[12,13]$} \\
\hline \multicolumn{4}{|c|}{ PROTEASE/PROTEASE INHIBITORS } \\
\hline CFAD & complement factor D & 2 (down) & {$[17,20]$} \\
\hline FETUB $^{\Delta}$ & fetuin B & 2 (down) & {$[11,12]$} \\
\hline PCS1N & $\begin{array}{l}\text { proprotein convertase subtilisin/kexin type } \\
\qquad 1 \text { inhibitor }\end{array}$ & 5 (down)* & {$[10,17,21,25,32]$} \\
\hline NEC2 & proprotein convertase subtilisin/kexin type 2 & 2 (down) & {$[12,21]$} \\
\hline
\end{tabular}


Table 1. Cont.

\begin{tabular}{|c|c|c|c|}
\hline Uniprot (Human) & Description & Identified in N Articles & References \\
\hline ZPI & serpin family A member 10 & 2 (down) & {$[12,13]$} \\
\hline THOP1 & thimet oligopeptidase 1 & 2 (up) & {$[12,20]$} \\
\hline UCHL1 & ubiquitin C-terminal hydrolase L1 & 3 (up) & {$[11,12,19]$} \\
\hline WFDC1 & WAP four-disulfide core domain 1 & 2 (down) & {$[12,20]$} \\
\hline \multicolumn{4}{|c|}{ OTHER FUNCTIONS } \\
\hline ARP21 & cAMP regulated phosphoprotein 21 & 2 (up) & {$[11,12]$} \\
\hline VAS1 & ATPase $\mathrm{H}+$ transporting accessory protein 1 & 2 (down) & {$[12,17]$} \\
\hline B3GN8 & $\begin{array}{c}\text { UDP-GlcNAc:betaGal } \\
\text { beta-1,3-N-acetylglucosaminyltransferase } 8\end{array}$ & $2($ down $)$ & {$[11,12]$} \\
\hline CH3L1 & chitinase 3 like 1 & 7 (up) & $\begin{array}{c}{[11,12,18,19,24,28,} \\
39]\end{array}$ \\
\hline CHIT1 & chitotriosidase- 1 & 3 (up) & {$[11,12,28]$} \\
\hline TETN & C-type lectin domain family 3 member B & 2 (down) & {$[12,29]$} \\
\hline $\mathrm{DDAH}^{\Delta}$ & dimethylarginine dimethylaminohydrolase 1 & 2 (up) & {$[12,20]$} \\
\hline FABPH & fatty acid binding protein 3 & 4 (up) & {$[10-12,25]$} \\
\hline FKB1A & FKBP prolyl isomerase $1 \mathrm{~A}$ & 2 (up) & {$[12,13]$} \\
\hline GUAD & guanine deaminase & 2 (up) & {$[11,12]$} \\
\hline HBG2 ${ }^{\Delta}$ & hemoglobin subunit gamma 2 & 2 (down) & {$[11,12]$} \\
\hline HPRT & hypoxanthine phosphoribosyltransferase 1 & 3 (up) & {$[10,12,13]$} \\
\hline OLR1 & oxidized low density lipoprotein receptor 1 & 2 (up) & {$[12,20]$} \\
\hline $\mathrm{AMD}^{\#, \varepsilon}$ & peptidylglycine alpha-amidating monooxygenase & 2 (up) & {$[15,20]$} \\
\hline PBIP1 & PBX homeobox interacting protein 1 & 2 (down) & {$[17,20]$} \\
\hline SLIT2 & slit guidance ligand 2 & 2 (up) & {$[12,35]$} \\
\hline SYWC & tryptophanyl-tRNA synthetase 1 & 2 (up) & {$[12,20]$} \\
\hline
\end{tabular}

The reference numbers correspond to those listed in Supplemental Table S1. *: Proteins identified with inverted pattern of expression in 1 additional article; \&: Proteins identified with inverted pattern of expression in two additional articles; $\$$ : $\beta$-Amyloid-interacting proteins \#: Proteins that bind copper; $\Delta$ : Proteins that bind metals. Down/up: protein down-up-regulated in the number of articles indicated; $\varepsilon$ : Proteins that were identified at least in one article that used a less novel technique such as two-dimensional gel electrophoresis (2-DE); C: cytokine; H: hormone.

\section{Variability of the Proteomic Approaches}

Several proteomic aproaches have been used during the last decade for the identification of biomarkers in AD CSF (indicated in Supplemental Table S1). As expected, the most used technique was LC-MS/MS, since nowadays is one of the most advanced approaches for biomarker identification [40]. Despite the existence of different proteomic approaches, several proteins were consistently found to be upregulated (Table 1). The better examples constitute CLUS (upregulated) and NPTXR (downregulated) which were found with similar trend in three different proteomic aproaches. Although we have to be cautious to compare different proteomic techniques due to the intrinsic differences in protein handling and identification, herein we verified that proteins such as TREM2, CSTN3, CD99, SODE, IBP6 and AMD display similar results irrespectively of whether LC-MS/MS or 2DE were employed (Table 1). Notwithstanding this, the specific information of proteins that were found to be altered in AD CSF as a consequence of the inclusion 2DE experiments is indicated in Table 1. Supplemental Table S1 also shows now the predominant technique used in the selected articles.

\section{Two Thirds of the of the Proteins That Change in the CSF of AD Are Intracellular}

While the identification of biomarkers in CSF is crucial to the understanding of AD, unveiling the source of the change is essential to reveal the biological mechanisms that underlie this pathology. Contrary to what we initially expected, given the reduced number of cells present in CSF (approximately 5 cells per $\mathrm{mL}$ that mainly correspond to lymphocytes and monocytes); [41], our study reveals that $66 \%$ of the CSF altered proteins identified across studies are intracellular proteins, mostly cytoplasmatic (39\%; Figure 2A). Amongst them, approximately $80 \%$ of the proteins (64) were increased in AD vs. controls. Taking 
into consideration the widely known neural death which occurs in AD [42], we would expect that a significant origin of these intracellular proteins in CSF may arise from remains of cellular debris that translocate to the CSF [43]. Furthermore, an increased infiltration of neutrophils has been observed during the development of $\mathrm{AD}$. Indeed, increased expression of $\mathrm{CD} 11 \mathrm{~b}$ positive neutrophils, which are directly related to neutrophil migration, positively correlated with the severity of AD. In this line, a higher number of neutrophils were found in brain vessels of $\mathrm{AD}$ patients when compared with controls of similar age [44].

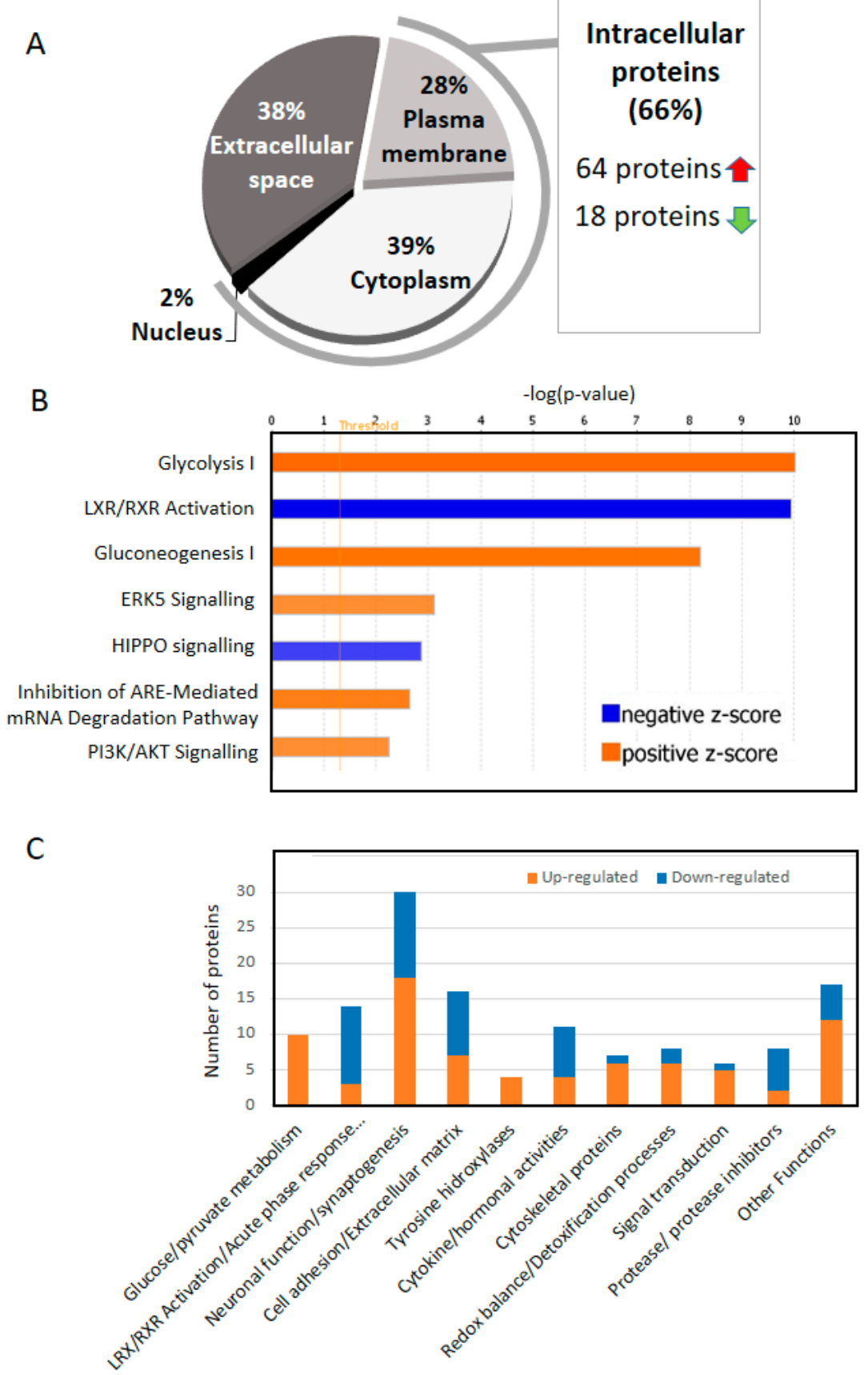

Figure 2. Information regarding proteins that consistently emerge across proteomic studies. (A) Schematic distribution of intracellular (plasma membrane and cytoplasm) and extracellular proteins (extracellular space). (B) Molecular pathways identified using IPA. Only those pathways with a - $\log (p$-value) over 2 and a $z$-score of + or -2 were considered. Positive $z$-scores are represented in orange. Negative z-scores are represented in blue. (C) Classification of the proteins according to their function. Data obtained from Table 1. 
Platelets are considered biomarkers for early diagnosis of AD (as reviewed in [45]). Treatment of platelets with $A \beta$ led to platelet activation and enhanced generation of reactive oxygen species (ROS) and membrane scrambling, suggesting enhanced platelet apoptosis [46]. Interestingly, among the top five pathways detected using Reactome, three of them were related to platelets. Specifically, this study has identified a total of 17 proteins directly related to platelet degranulation $\left(p\right.$-value $\left.2.1 \times 10^{-11}\right)$ and or platelet aggregation $\left(p\right.$-value $\left.1.1 \times-10^{-07}\right)$ (Supplemental Table S2). Whether this finding is related to increased apoptosis requires further investigation.

Together with the cells discussed above an additional source for membrane proteins are exosomes. In this sense, it was previously shown that $1 \mathrm{~mL}$ of human CSF contains $\sim 2 \mu \mathrm{g}$ of endogenous exosomes [47]. The finding that exosomes isolated from human CSF or brain samples sequestered oligomeric $A \beta$ in the brain has led to propose their protective role in AD pathogenesis [47]. Indeed, several proteins of our database such as CHL1, KNG1, or APOA1 were found to be constituents of human CSF exosomes [48].

\section{Increased Glucose/Pyruvate Metabolism in AD CSF}

A variety of proteins related to glucose metabolism were found altered in CSF to the extent that glycolysis and gluconeogenesis constitute the two metabolic pathways most represented in our study ( $p$-value $9.5 \times 10^{-11}$ and $6 \times 10^{-9}$, respectively; Figure 2B,C). Furthermore, all the proteins related to glucose metabolism appeared increased in $\mathrm{AD}$ CSF (z-score 2.65, Table 1). Most of the identified proteins are common enzymes for both processes, glycolysis and gluconeogenesis (Figure 3).

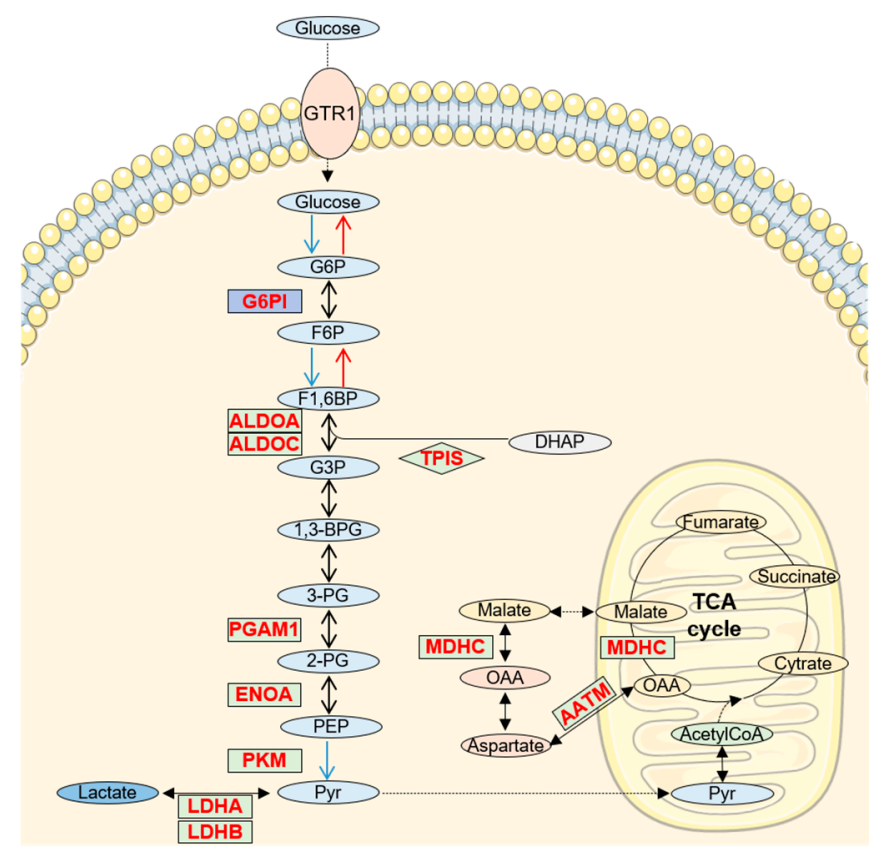

Figure 3. Alteration of glucose/pyruvate metabolism in AD CSF. Schematic representation of glycolysis, gluconeogenesis and pyruvate metabolism. Proteins that increase in AD CSF are labelled in red and green indicates decreased proteins. G6P: glucose-6-phosphate; F6P: Fructose-6-phosphate; G3P: glyceraldehide-3-phosphate; 1,3-BPG: 1,3-Biphosphoglycerate; 3PG: 3-phosphoglyucerate; 2PG: 2-phosphoglycerate; PEP: phosphoenolpyruvate; Pyr: pyruvate; OAA: oxalacetate. Background images were created using templates from Servier Medical Art, which are licensed under a Creative Commons Attribution 3.0 Unported License (http:/ / smart.servier.com/ accessed on 5 July 2021).

It is also important to mention the glycolytic enzyme pyruvate kinase M1/2 (KPYM), that catalyzes the synthesis of pyruvate from phosphoenolpyruvate [49] and the lactate dehydrogenase $(\mathrm{LDH})$, which reduces pyruvate to lactate through a reversible reaction, thus allowing cells to generate or consume lactate depending on their metabolic profile. 
Impaired glucose metabolism has been widely recognized as an early feature in the brain of subjects with AD since alteration of brain aerobic glycolysis is frequently observed in the course of $\mathrm{AD}[50,51]$. It has also been proposed that reduced glucose availability in $\mathrm{AD}$ would force the brain to rely on gluconeogenesis (de novo synthesis of glucose). Interestingly, despite the low brain glucose uptake in $\mathrm{AD}$, most post-mortem studies show consistent upregulation in glycolytic enzyme proteins [51,52], thus suggesting a compensatory mechanism for the low glucose supply in order to overcome a compromised mitochondrial function. In conclusion, evaluation of an increase of proteins directly related to glucose metabolism in CSF may reveal what takes place in surrounding tissues during AD progression.

\section{RXR Signaling in CSF (LXR/RXR Activation Pathway)}

One of the most relevant findings of this study is the significant reduction $(p$-value $=$ $1.1 \times 10^{-10}$ ) of proteins participating in the Liver X Receptor $(\mathrm{LXR}) /$ Retinoid X receptor (RXR) pathway in CSF from AD patients (z-score 2.7; Figure 2B,C). LXR/RXR activation pathway (Figure 4) is involved in a variety of processes associated with cholesterol metabolism, inflammation, oxidative stress, etc. $[53,54]$. Although LXR/RXR pathway represents a relevant pathway altered in $\mathrm{AD}[53,55]$, as far as we know, this is the first relevant mention of an overall reduction of LXR/RXR activation in AD CSF. In line with our observations, previous works have detected a reduction in the expression of LXR- $\beta$ in plasma of AD patients compared to control samples [56]. Furthermore, the LXR/RXR pathway was also reduced in plasma samples of PSAPP and hTau mice models [57]. Retinoids modulate the expression of different key proteins in AD, as presenilin 1 (PS1), metalloprotease 10 (ADAM 10) or $\beta$-secretase [58,59]. Moreover, retinoic acid (RA) may have a central role in the pathophysiology of $\mathrm{AD}$ and reduced brain levels of this metabolite would constitute a risk factor for the development of the disease. Different mutations on the RA receptors can misregulate AD candidate genes such as PS1, ADAM 10, PS2 or APP [53].

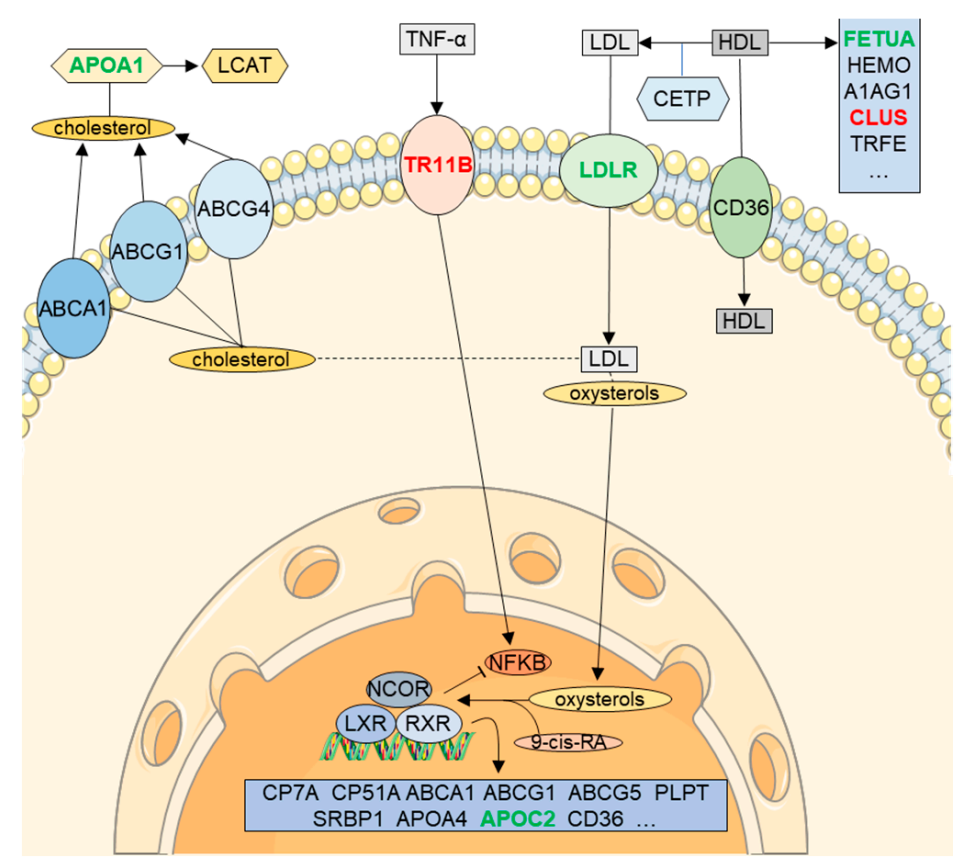

Figure 4. Alteration of LXR/RXR activation pathway in AD CSF. Summarized representation of the LXR/RXR activation pathway. Proteins that increase in AD CSF are labelled in red and green indicates decreased proteins. Background images were created using templates from Servier Medical Art, which are licensed under a Creative Commons Attribution 3.0 Unported License (http:/ / smart.servier.com/ accessed on 5 July 2021). 
As we pointed out, a reduction in the LRX activation was predicted with high confidence. This decrease might be related to the advanced development of the pathology, since LXR activation plays a key role in plaque reduction by increasing clearance, thereby improving cognitive impairment $[60,61]$. Furthermore, genetic loss of LXR in APP/PS1 mice induced a greater accumulation of A $\beta$ plaques [62], while loss of LXR in healthy mice triggered neurodegeneration [63]. Therefore, decreased LXR/RXR pathway components in CSF may inversely correlate with $A \beta$ deposition in tissues.

Another function of the LXR/RXR pathway comprises the activation of apolipoproteins that may serve as cholesterol acceptors [64]. Apolipoproteins constitute a family of proteins with a key role in transport and delivery of lipids, cholesterol homeostasis, and central nervous system (CNS) remodeling [65]. In this study, we observed decreased levels of different apolipoproteins (APOA1, APOC2, and APOL1) in CSF. APOA1, one of the most abundant proteins in human CSF, has been identified as part of senile plaques of $\mathrm{AD}$ patients' brains [66]. A link between the presence of APOC2 and familial Alzheimer's was observed decades ago [67], although, to date, its specific role in late-onset AD (LOAD) is still unknown. Similarly, APOL1 has been related to other pathologies such as kidney disease [68], while a direct link with AD has not been established yet.

\section{Neuronal Function/Synaptogenesis}

The organization of the proteins according to their function (Table 1 and Figure 2C) revealed that a high number of them were directly related to neuronal function and specially, synaptogenesis. Synaptogenesis is a dynamic process by which the formation and stabilization of synapses occur in the CNS [69]. In neurodegenerative diseases, such as $\mathrm{AD}$, synaptic degeneration and synapse loss have been described as early events that precede neuronal death $[70,71]$. Indeed, several studies have proposed a role for synaptic proteins as specific biomarkers for AD in CSF [7,44,45].

The clearest reflection in CSF of the synaptic degeneration that occurs in AD is the family of 'long' neuronal pentraxins (NPTX1, NPTX2) and its receptor NPTXR since they constitute the most consistently decreased proteins in CSF and they display a direct function in neural differentiation [72], synaptogenesis [73] and synaptic plasticity [74-76]. Specifically, these proteins form mixed NPTX complexes which traffic to the extracellular surface at excitatory synapses where they interact with postsynaptic glutamate receptors [77,78]. Taken together, these three proteins were found to decrease in 8 different proteomic studies. The parallel and consistent decrease of these proteins in CSF would not fit with our previous suggestion of increased neuronal cell death. However, different studies have already described a down-regulation of NPTX2 in AD brains [79,80]. It has also been described that NPTX1 is accumulated in dystrophic neurites and surround plaques in postmortem AD brains [81-83], which would explain their decreased levels in CSF. Therefore, the inverse correlation of pentraxins amount in plaques/CSF could be a good indicator of neuronal death and/or synaptic loss.

Similarly, neurexins (NRX), one of the best-characterized families of presynaptic organizers, appeared reduced in 6 different studies. Likewise NPTX1, two of the three family members (NRX1 and NRX2) have been proposed as direct targets of $A \beta$ oligomers [84]. In the same line, calsyntenin-3 (CSTN3), a direct NRX interactor $[85,86]$ was also found to decrease in CSF. This transmembrane protein of the cadherin superfamily is distributed in postsynaptic membranes throughout the adult brain [87]. As occur with NPTX1, CSTN3 accumulates in dystrophic neurite surrounding $\mathrm{A} \beta$ plaques [88].

In view of these studies, we have to take into consideration that several proteins may not be released to the CSF and, oppositely, they might somehow be accumulated into the plaque in a process that could be carried out by $\mathrm{A} \beta$ and tau aggregation, thus ultimately driving a reduction of certain proteins in CSF. This may explain the variability observed across proteins not only directly involved in neuronal function but also those related to cell adhesion and components of the cell-matrix (Table 1 and Figure 2C). Although at different levels, 21 of these proteins decreased while 25 increased in CSF. The best example 
that reflects this heterogeneity raises from the members of the SPRC family. Based on our results, four members of this family are differently altered in AD CSF. This family of proteins comprises six members that present calcium-binding domains and regulate cell interaction with the microenvironment [89]. It is worth highlighting the potential role of SPRC on vascular pathology in AD. In the brain, SPRC is also expressed in endothelial cells, wherein it affects trans-endothelial permeability [89]. Moreover, since it acts as a chaperone of collagen IV through the SPRC-collagen binding domain, it has been observed a direct relationship between increased SPRC, collagen IV, and the thickening of the basal lamina of the cerebral vasculature, a feature commonly observed in AD brains [89-91].

Notwithstanding this, according to our study, SMOC1 was consistently upregulated in AD CSF in seven different studies (Table 1), thus making it a potential biomarker. Among its functions, SMOC1 promotes endothelial proliferation [92], and although it is overexpressed in AD brains, wherein it colocalizes with $\mathrm{A} \beta$ plaques $[93,94]$, its specific role in AD is still unknown. Conversely, testican-1 (TICN1) was consistently downregulated in AD CSF. Different studies have shown a link between TICN1 overexpression in the brain and $\mathrm{AD}$ [95]. It surrounds $\mathrm{A} \beta$ plaques in brains of $\mathrm{AD}$ patients [95] and regulates proteins related to A $\beta$ production and degradation, such as MMP2 or cathepsin-L [96,97]. Finally, it has been linked to APP sorting. Therefore, as we have previously proposed for other proteins, lower CSF levels of this protein may indicate an accumulation in the brain during the development of the pathology [95].

\section{14-3-3 Proteins Are up Regulated in CSF}

The 14-3-3 family consists of seven highly homologous molecules that were first reported as regulators of tyrosine hydroxylase (TH) activity [98], four of which were consistently upregulated in the CSF of AD. These proteins have recently been linked to a variety of processes such as regulation of protein interaction and localization or transcription since they have a nuclear localization sequence [99]. It has been reported that 14-3-3 proteins regulate neuronal differentiation, morphogenesis and migration [100]. The expression of these proteins increases in cortical regions of AD patients and, even though they have not been observed in $\mathrm{A} \beta$ plaques, some evidence connects them with neurofibrillary tangles [99]. However, 14-3-3 family members cannot be considered suitable markers for differential diagnosis of AD [101,102] since they have also been detected in CSF of all dementia patients, thus suggesting their role as common markers for neurodegenerative diseases.

\section{Cytokines and Hormones up and down Regulated in CSF}

Five of the proteins in this section correspond to members of the granin family of proteins (chromogranins, secretogranins and VGF). These precursors of biologically active peptides and the products of their proteolitical cleavage have been proposed as biomarkers of different neurological diseases, included AD [103,104].

As expected, among them, VGF was the most consistent downregulated protein among the identified secreted proteins with biological activities. This protein is nowadays considered one of the best AD markers in CSF as it is consistently reduced in CSF of these patients [7].

Another remarkable protein that was consistently reduced in CSF was somatostatin (SMS). A long time ago it was proposed that diminished levels of somatostatin in CSF may be a specific AD signature compared to other neurodegenerative pathologies as Parkinson's $[105,106]$. Whereas the reason for this reduction as a consequence of the prepropeptide processing remains elusive, it has been recently reported that its deficiency has a direct link with a loss of integrity of the BBB in A $\beta$-induced toxicity [107].

On the contrary, among the four proteins in this group that appear increased, phosphoprotein 1 (SPP1, also called osteopontin) was found to be the most consistent upregulated protein (increased in seven different studies). This extracellular phosphoprotein is expressed in response to stress and injury and regulates macrophage infiltration and cytokine production $[108,109]$. In the past years, SPP1 has been linked to inflammation-associated 
neurological disease. Indeed, higher SPP1 levels have already been described in brain and CSF in AD patients $[110,111]$.

\section{Importance of Cofactors in CSF}

Herein, we explored common affinities of the identified proteins for given cofactors. Interestingly, copper $\left(\mathrm{Cu}^{2+}\right)$ emerged as the most common cofactor for several of the identified proteins (indicated in Table 1). Several meta-analysis have identified changes in $\mathrm{Cu}^{2+}$ concentration in brain and serum (reviewed by [112]), although conflicting evidence of copper's role in AD has been pointed $([113,114]$, reviewed by [115]). It is well known that $\mathrm{Cu}^{2+}$ and $\mathrm{Zn}^{2+}$ interact with $\mathrm{A} \beta$ peptides with high affinity and these interactions have been proposed to accelerate $A \beta_{1-40}$ and $A \beta_{1-42}$ aggregation in vitro, thus contributing to their toxicity, ROS generation, and the development of $A \beta$ neurotoxicity [116]. Nonetheless, the mechanism that $\mathrm{Cu}^{2+}$ utilizes to reach the brain is partially understood. Together with albumin (ALBU), the main protein needed for passive diffusion of $\mathrm{Cu}^{2+}$ through the bloodCSF barrier to the brain is ceruloplasmin (CERU) [117]. The fact that both proteins seem to behave inversely in CSF AD, showing decreased levels of ALBU and increased CERU, indicate that the equilibrium of $\mathrm{Cu}^{2+}$ transport in CSF is altered in AD.

Further evidence of the implication of $\mathrm{Cu}^{2+}$ in $\mathrm{AD}$ would be represented by metallothionein 3 (MT3), which regulates $\mathrm{Cu}^{2+}$ and $\mathrm{Zn}^{2+}$ transport and storage in CNS and inhibits their toxicity, thus representing one of the major players in metal homeostasis [118]. Conversely, the peptidylglycine $\alpha$-amidating monooxygenase (AMD), a copper-dependent enzyme that regulates the secretory pathway, was found increased in CSF from AD patients. In mammals, AMD is essential to catalyze $\alpha$-amidation, a necessary step to confer full biological activity to many neuropeptides $[119,120]$. Herein, we report for the first time the potential use of AMD as a consistent AD marker in CSF. Furthermore, to our knowledge, there is only one study investigating AMD in CSF where a reduction in enzyme activity in AD samples as compared to healthy, age-matched control was proposed, thus suggesting neuronal dysfunction within the CNS in AD patients [121].

\section{Other amyloid $\beta$ Interactors}

The present analysis showed an increase in CLUS (APOJ) levels in CSF, which is in line with previous findings $[122,123]$. CLUS reduces aggregation and promotes clearance of $A \beta$ at the blood-brain barrier under physiological conditions, suggesting that this protein, as proposed for SMS, may accumulate in CSF as a consequence of failed perivascular drainage of interstitial fluid [122].

Triggering receptor expressed on myeloid cells 2 (TREM2) has been shown to play a role in the phagocytosis of apoptotic neuronal cells [124] and it has been recently identified as a microglial $\mathrm{A} \beta$ receptor that transduces physiological and AD-related pathological effects associated with $A \beta$ [125]. Several studies have shown that the loss-of-function mutations of TREM2 variants are linked to increased AD risk [126,127]. Additionally, increased TREM expression has been observed in AD patients suggesting an association between TREM2 levels and apoptosis in AD [128], though this is the first demonstration of its consistent increase in CSF.

A role for the metalloendopeptidase THOP1 as a potential $\beta$-secretase candidate was demonstrated by Koike et al., since it cleaves the full-length APP when overexpressed in COS cells [129]. This enzyme also promotes soluble $A \beta$ degradation while no degradation was observed in aggregated $A \beta$ [130]. THOP1 expression was significantly increased in human AD brain tissue as compared to non-demented controls, suggesting that increased THOP1 expression might be part of a compensatory defense mechanism of the brain against high $A \beta$ load [131]. Herein, we have found a direct correlation of the data described in brain tissue with that of CSF. 


\section{New Potential AD Markers}

Together with the above highlighted information for MT3, TREM2, THOP1 or AMD, other potential AD markers in CSF emerge from this study. Although several of our candidates have already been proposed as markers in post-mortem tissue, their relevance in CSF has not been unveiled. Therefore, the proteins mentioned below correspond to those unique proteins from Table 1 whose information regarding to $\mathrm{AD}$, to our knowledge, is very limited or unexistent.

\subsection{Ubiquitin C-Terminal Hydrolase L1 (UCHL1)}

Only a few reports address the implications of UCH-L1 genetic variation in AD [132,133], and, although this is the first study that shows a recurrent increase of these proteins in CSF by proteomic approaches, its increase in CSF has been verified by other methodologies [134].

\subsection{C-X-C Motif Chemokine Ligand 16 (CXL16)}

CXL16 is produced by dendritic cells and it is known to attract lymphocyte subsets [135], especially, natural killer (NK) cells that express its receptor [136]. NK cells play an important role in the host defense, which is related to their ability to secrete a variety of cytokines and chemokines, as well as killing infected host cells (reviewed by [137]). Therefore, this marker might be a good target to detect AD-related neuroinflammation via CSF.

\subsection{Protein Kinase C and Casein Kinase Substrate in Neurons 1 (PACN1)}

PACN1 is required for the activity-dependent internalization of AMPA receptor, a key regulator of synaptic plasticity, which is thought to be one of the key cellular components underlying learning and memory. An increase in the number of synaptic AMPARs leads to long-term potentiation (LTP), whereas the removal of surface AMPARs by endocytosis results in long-term depression (LTD) [138]. PACN1 also regulates activity-dependent retrieval of synaptic vesicles in the presynaptic terminals [139]. It has been implicated in various neurodegenerative diseases (Parkinson's disease and AD) [140,141].

\subsection{Protein Tyrosine Phosphatase Receptor Type Z1 (PTPRZ)}

A thorough search through the literature allowed us to identify one bioinformatic study that speculated the possibility that PTPRZ may regulate the cognitive and memory pathways through the CNS, thereby promoting the development of AD [142]. It remains to be investigated whether this observation is accurate, although our collected data clearly support this concept as we also found a concomitant increase of these phosphatases in AD CSF.

\subsection{Integrin Subunit Alpha M (ITAM)}

To our knowledge, this protein has never been associated with AD. Remarkably, a recent work studied genetic variability of 4 new genes, one of which encodes ITAM, which were predicted to contain variants associated with $\mathrm{AD} \mathrm{[143].} \mathrm{According} \mathrm{to} \mathrm{our} \mathrm{analysis,}$ this protein appears consistently increased across proteomic studies. Therefore, our study constitutes the first nexus between gene expression and protein increase of this integrin.

\subsection{Myristoylated Alanine-Rich Protein Kinase C Substrate (MARCS)}

MARCS is an interesting innovative marker of AD in CSF, since little is known about its relationship with AD. MARCS phosphorylation at Ser46 has been shown to constitute a hallmark of neurite degeneration [116] and there are studies that point towards the beneficial effects of increased MARCS levels for memory improvement [144].

\section{Conclusions}

Every year there is an increasing number of published articles that take advantage of evolving state-of-the-art technologies to identify/propose new biomarkers of neurode- 
generative diseases. This is especially evident when we perform a literature search of proteomics, CSF, and AD. Therefore, a continuous revision of the results is mandatory to redefine with extreme accuracy new potential biomarkers that may help to identify prodromal or initial stages of the devastating neurodegenerative disease that represents AD. Herein, we aimed at understanding the importance of clusters of proteins that share similar functions in AD pathology also indicating a potential explanation of their up- or down-regulation in CSF. Although this is a study of a database generated with previous proteomic studies and bioinformatics analysis it must be taken with caution, we propose herein certain proteins as potential new biomarkers since they consistently appear up- or down-regulated in AD CSF. Whether proteins such as TREM2, THOP1, AMD, or ITAM constitute good biomarkers will be confirmed by further proteomics studies that will certainly appear.

Supplementary Materials: The following are available online at https:/ / www.mdpi.com/article/10 .3390/diagnostics11091655/s1, Table S1: Database information. Table S2: Reactome analysis.

Author Contributions: Conceptualization, C.M.P.-P., J.R.P. and Y.R.-R.; methodology, C.M.P.-P., J.F.-R. and J.R.P.; bioinformatics, J.R.P., J.F.-R., M.D.-P. and C.M.P.-P.; data curation, C.M.P.-P., J.F.-R. and J.R.P.; writing—original draft preparation, Y.R.-R., C.M.P.P., F.J.A. and J.R.P.; writing—review and editing, M.D.-P., F.J.A., J.R.P. and Y.R.-R.; supervision, Y.R.-R. and J.R.P. All authors have read and agreed to the published version of the manuscript.

Funding: This review has been funded by grants from the Consejería de Educación de la Junta de Comunidades de Castilla-La Mancha (grant number SBPLY/19/180501/000245, to Y.R.-R.); Universidad de Castilla-La Mancha (2020-GRIN-29101 to F.J.A.); MINECO-RETOS (AEI-FEDER) and "Plan Propio de Investigación" FEDER/UCLM 2021 to M.D.-P. Y.R.-R. is financed by FEDER (2018/D/LD/MC/8). The study was sponsored by the UCLM/ERDF (2020-GRIN-29145 to NPND), Spanish Ministries of Economy and Competitiveness/ERDF (grant no. SAF2016-75768-R) and Science and Innovation (grant no. PID2019-108659RB-I00) and Autonomous Government of Castilla- La Mancha/ERDF (grant no. SBPLY/17/180501/000430). The funders were not involved in the design, data collection, analysis or preparation of the review.

Institutional Review Board Statement: Not applicable.

Informed Consent Statement: Not applicable.

Data Availability Statement: Al data generated in this review are included in the article in the form of tables and supplemental tables.

Acknowledgments: Background images in Figures 3 and 4 were modified from Servier Medical Art, licensed under a Creative Common Attribution 3.0 Unported License. http:/ / smart.servier.com (Last access 5 July 2021).

Conflicts of Interest: The authors declare no conflict of interest.

\section{References}

1. Llorens, F.; Schmitz, M.; Ferrer, I.; Zerr, I. CSF biomarkers in neurodegenerative and vascular dementias. Prog. Neurobiol. 2016, 138-140, 36-53. [CrossRef]

2. Solje, E.; Benussi, A.; Buratti, E.; Remes, A.M.; Haapasalo, A.; Borroni, B. State-of-the-Art Methods and Emerging Fluid Biomarkers in the Diagnostics of Dementia-A Short Review and Diagnostic Algorithm. Diagnostics 2021, 11, 788. [CrossRef] [PubMed]

3. Wu, C.-Y.; Bawa, K.K.; Ouk, M.; Leung, N.; Yu, D.; Lanctôt, K.L.; Herrmann, N.; Pakosh, M.; Swardfager, W. Neutrophil activation in Alzheimer's disease and mild cognitive impairment: A systematic review and meta-analysis of protein markers in blood and cerebrospinal fluid. Ageing Res. Rev. 2020, 62, 101130. [CrossRef]

4. McGrowder, D.A.; Miller, F.; Vaz, K.; Nwokocha, C.; Wilson-Clarke, C.; Anderson-Cross, M.; Brown, J.; Anderson-Jackson, L.; Williams, L.; Latore, L.; et al. Cerebrospinal Fluid Biomarkers of Alzheimer's Disease: Current Evidence and Future Perspectives. Brain Sci. 2021, 11, 215. [CrossRef]

5. Baird, A.L.; Westwood, S.; Lovestone, S. Blood-Based Proteomic Biomarkers of Alzheimer's Disease Pathology. Front. Neurol. 2015, 6, 236. [CrossRef] [PubMed]

6. Blennow, K. Cerebrospinal fluid protein biomarkers for Alzheimer's disease. NeuroRX 2004, 1, 213-225. [CrossRef] 
7. Pedrero-Prieto, C.M.; García-Carpintero, S.; Frontiñán-Rubio, J.; Llanos-González, E.; Aguilera García, C.; Alcaín, F.J.; Lindberg, I.; Durán-Prado, M.; Peinado, J.R.; Rabanal-Ruiz, Y. A comprehensive systematic review of CSF proteins and peptides that define Alzheimer's disease. Clin. Proteom. 2020, 17, 1-24. [CrossRef]

8. Wesenhagen, K.E.J.; Teunissen, C.E.; Visser, P.J.; Tijms, B.M. Cerebrospinal fluid proteomics and biological heterogeneity in Alzheimer's disease: A literature review. Crit. Rev. Clin. Lab. Sci. 2019, 57, 86-98. [CrossRef]

9. Fabregat, A.; Sidiropoulos, K.; Viteri, G.; Forner, O.; Marin-Garcia, P.; Arnau, V.; D’Eustachio, P.; Stein, L.; Hermjakob, H. Reactome pathway analysis: A high-performance in-memory approach. BMC Bioinform. 2017, 18, 142. [CrossRef]

10. McKetney, J.; Panyard, D.J.; Johnson, S.C.; Carlsson, C.M.; Engelman, C.D.; Coon, J.J. Pilot proteomic analysis of cerebrospinal fluid in Alzheimer's disease. Proteom. Clin. Appl. 2021, 15, e2000072. [CrossRef]

11. Zhou, M.; Haque, R.U.; Dammer, E.B.; Duong, D.M.; Ping, L.; Johnson, E.C.B.; Lah, J.J.; Levey, A.I.; Seyfried, N.T. Targeted mass spectrometry to quantify brain-derived cerebrospinal fluid biomarkers in Alzheimer's disease. Clin. Proteom. 2020, 17, 19. [CrossRef]

12. Higginbotham, L.; Ping, L.; Dammer, E.B.; Duong, D.M.; Zhou, M.; Gearing, M.; Hurst, C.; Glass, J.D.; Factor, S.A.; Johnson, E.C.B.; et al. Integrated proteomics reveals brain-based cerebrospinal fluid biomarkers in asymptomatic and symptomatic Alzheimer's disease. Sci. Adv. 2020, 6, aaz9360. [CrossRef] [PubMed]

13. Bader, J.M.; Geyer, P.E.; Muller, J.B.; Strauss, M.T.; Koch, M.; Leypoldt, F.; Koertvelyessy, P.; Bittner, D.; Schipke, C.G.; Incesoy, E.I.; et al. Proteome profiling in cerebrospinal fluid reveals novel biomarkers of Alzheimer's disease. Mol. Syst. Biol. 2020, 16, e9356. [CrossRef] [PubMed]

14. Dayon, L.; Nunez Galindo, A.; Wojcik, J.; Cominetti, O.; Corthesy, J.; Oikonomidi, A.; Henry, H.; Kussmann, M.; Migliavacca, E.; Severin, I.; et al. Alzheimer disease pathology and the cerebrospinal fluid proteome. Alzheimers Res. Ther. 2018, 10, 66. [CrossRef] [PubMed]

15. Ringman, J.M.; Schulman, H.; Becker, C.; Jones, T.; Bai, Y.; Immermann, F.; Cole, G.; Sokolow, S.; Gylys, K.; Geschwind, D.H.; et al. Proteomic changes in cerebrospinal fluid of presymptomatic and affected persons carrying familial Alzheimer disease mutations. Arch. Neurol. 2012, 69, 96-104. [CrossRef] [PubMed]

16. Johnson, E.C.B.; Dammer, E.B.; Duong, D.M.; Ping, L.; Zhou, M.; Yin, L.; Higginbotham, L.A.; Guajardo, A.; White, B.; Troncoso, J.C.; et al. Large-scale proteomic analysis of Alzheimer's disease brain and cerebrospinal fluid reveals early changes in energy metabolism associated with microglia and astrocyte activation. Nat. Med. 2020, 26, 769-780. [CrossRef]

17. Khoonsari, P.E.; Haggmark, A.; Lonnberg, M.; Mikus, M.; Kilander, L.; Lannfelt, L.; Bergquist, J.; Ingelsson, M.; Nilsson, P.; Kultima, K.; et al. Analysis of the Cerebrospinal Fluid Proteome in Alzheimer's Disease. PLoS ONE 2016, 11, e0150672. [CrossRef] [PubMed]

18. Paterson, R.W.; Heywood, W.E.; Heslegrave, A.J.; Magdalinou, N.K.; Andreasson, U.; Sirka, E.; Bliss, E.; Slattery, C.F.; Toombs, J.; Svensson, J.; et al. A targeted proteomic multiplex CSF assay identifies increased malate dehydrogenase and other neurodegenerative biomarkers in individuals with Alzheimer's disease pathology. Transl. Psychiatry 2016, 6, e952. [CrossRef]

19. Heywood, W.E.; Galimberti, D.; Bliss, E.; Sirka, E.; Paterson, R.W.; Magdalinou, N.K.; Carecchio, M.; Reid, E.; Heslegrave, A.; Fenoglio, C.; et al. Identification of novel CSF biomarkers for neurodegeneration and their validation by a high-throughput multiplexed targeted proteomic assay. Mol. Neurodegener. 2015, 10, 64. [CrossRef] [PubMed]

20. Sathe, G.; Na, C.H.; Renuse, S.; Madugundu, A.K.; Albert, M.; Moghekar, A.; Pandey, A. Quantitative Proteomic Profiling of Cerebrospinal Fluid to Identify Candidate Biomarkers for Alzheimer's Disease. Proteom. Clin. Appl. 2019, 13, e1800105. [CrossRef]

21. Holtta, M.; Minthon, L.; Hansson, O.; Holmen-Larsson, J.; Pike, I.; Ward, M.; Kuhn, K.; Ruetschi, U.; Zetterberg, H.; Blennow, K.; et al. An integrated workflow for multiplex CSF proteomics and peptidomics-identification of candidate cerebrospinal fluid biomarkers of Alzheimer's disease. J. Proteome Res. 2015, 14, 654-663. [CrossRef]

22. Alzate, O.; Osorio, C.; DeKroon, R.M.; Corcimaru, A.; Gunawardena, H.P. Differentially charged isoforms of apolipoprotein E from human blood are potential biomarkers of Alzheimer's disease. Alzheimers Res. Ther. 2014, 6, 43. [CrossRef] [PubMed]

23. Chakrabarti, A.; Chatterjee, A.; Sengupta, M.B.; Chattopadhyay, P.; Mukhopadhyay, D. Altered levels of amyloid precursor protein intracellular domain-interacting proteins in Alzheimer disease. Alzheimer Dis. Assoc. Disord. 2014, 28, 283-290. [CrossRef]

24. Khoonsari, P.E.; Shevchenko, G.; Herman, S.; Remnestal, J.; Giedraitis, V.; Brundin, R.; Degerman Gunnarsson, M.; Kilander, L.; Zetterberg, H.; Nilsson, P.; et al. Improved Differential Diagnosis of Alzheimer's Disease by Integrating ELISA and Mass Spectrometry-Based Cerebrospinal Fluid Biomarkers. J. Alzheimer's Dis. 2019, 67, 639-651. [CrossRef] [PubMed]

25. Spellman, D.S.; Wildsmith, K.R.; Honigberg, L.A.; Tuefferd, M.; Baker, D.; Raghavan, N.; Nairn, A.C.; Croteau, P.; Schirm, M.; Allard, R.; et al. Development and evaluation of a multiplexed mass spectrometry based assay for measuring candidate peptide biomarkers in Alzheimer's Disease Neuroimaging Initiative (ADNI) CSF. Proteom. Clin. Appl. 2015, 9, 715-731. [CrossRef]

26. Skillback, T.; Mattsson, N.; Hansson, K.; Mirgorodskaya, E.; Dahlen, R.; van der Flier, W.; Scheltens, P.; Duits, F.; Hansson, O.; Teunissen, C.; et al. A novel quantification-driven proteomic strategy identifies an endogenous peptide of pleiotrophin as a new biomarker of Alzheimer's disease. Sci. Rep. 2017, 7, 13333. [CrossRef]

27. Manral, P.; Sharma, P.; Hariprasad, G.; Chandralekha; Tripathi, M.; Srinivasan, A. Can apolipoproteins and complement factors be biomarkers of Alzheimer's disease? Curr. Alzheimer Res. 2012, 9, 935-943. [CrossRef]

28. Whelan, C.D.; Mattsson, N.; Nagle, M.W.; Vijayaraghavan, S.; Hyde, C.; Janelidze, S.; Stomrud, E.; Lee, J.; Fitz, L.; Samad, T.A.; et al. Multiplex proteomics identifies novel CSF and plasma biomarkers of early Alzheimer's disease. Acta Neuropathol. Commun. 2019, 7, 169. [CrossRef] [PubMed] 
29. Vafadar-Isfahani, B.; Ball, G.; Coveney, C.; Lemetre, C.; Boocock, D.; Minthon, L.; Hansson, O.; Miles, A.K.; Janciauskiene, S.M.; Warden, D.; et al. Identification of SPARC-like 1 protein as part of a biomarker panel for Alzheimer's disease in cerebrospinal fluid. J. Alzheimer's Dis. JAD 2012, 28, 625-636. [CrossRef] [PubMed]

30. Remnestal, J.; Just, D.; Mitsios, N.; Fredolini, C.; Mulder, J.; Schwenk, J.M.; Uhlen, M.; Kultima, K.; Ingelsson, M.; Kilander, L.; et al. CSF profiling of the human brain enriched proteome reveals associations of neuromodulin and neurogranin to Alzheimer's disease. Proteom. Clin. Appl. 2016, 10, 1242-1253. [CrossRef]

31. Brinkmalm, G.; Sjodin, S.; Simonsen, A.H.; Hasselbalch, S.G.; Zetterberg, H.; Brinkmalm, A.; Blennow, K. A Parallel Reaction Monitoring Mass Spectrometric Method for Analysis of Potential CSF Biomarkers for Alzheimer's Disease. Proteom. Clin. Appl. 2018, 12. [CrossRef] [PubMed]

32. Wang, J.; Cunningham, R.; Zetterberg, H.; Asthana, S.; Carlsson, C.; Okonkwo, O.; Li, L. Label-free quantitative comparison of cerebrospinal fluid glycoproteins and endogenous peptides in subjects with Alzheimer's disease, mild cognitive impairment, and healthy individuals. Proteom. Clin. Appl. 2016, 10, 1225-1241. [CrossRef]

33. Nilsson, J.; Gobom, J.; Sjodin, S.; Brinkmalm, G.; Ashton, N.J.; Svensson, J.; Johansson, P.; Portelius, E.; Zetterberg, H.; Blennow, K.; et al. Cerebrospinal fluid biomarker panel for synaptic dysfunction in Alzheimer's disease. Alzheimers Dement. (Amst.) 2021, 13, e12179. [CrossRef] [PubMed]

34. Hendrickson, R.C.; Lee, A.Y.; Song, Q.; Liaw, A.; Wiener, M.; Paweletz, C.P.; Seeburger, J.L.; Li, J.; Meng, F.; Deyanova, E.G.; et al. High Resolution Discovery Proteomics Reveals Candidate Disease Progression Markers of Alzheimer's Disease in Human Cerebrospinal Fluid. PLoS ONE 2015, 10, e0135365. [CrossRef] [PubMed]

35. Wang, H.; Dey, K.K.; Chen, P.C.; Li, Y.; Niu, M.; Cho, J.H.; Wang, X.; Bai, B.; Jiao, Y.; Chepyala, S.R.; et al. Integrated analysis of ultra-deep proteomes in cortex, cerebrospinal fluid and serum reveals a mitochondrial signature in Alzheimer's disease. Mol. Neurodegener. 2020, 15, 43. [CrossRef] [PubMed]

36. Park, S.A.; Jung, J.M.; Park, J.S.; Lee, J.H.; Park, B.; Kim, H.J.; Park, J.H.; Chae, W.S.; Jeong, J.H.; Choi, S.H.; et al. SWATH-MS analysis of cerebrospinal fluid to generate a robust battery of biomarkers for Alzheimer's disease. Sci. Rep. 2020, $10,7423$. [CrossRef] [PubMed]

37. Duits, F.H.; Brinkmalm, G.; Teunissen, C.E.; Brinkmalm, A.; Scheltens, P.; Van der Flier, W.M.; Zetterberg, H.; Blennow, K. Synaptic proteins in CSF as potential novel biomarkers for prognosis in prodromal Alzheimer's disease. Alzheimer's Res. Ther. 2018, 10, 5. [CrossRef] [PubMed]

38. Wijte, D.; McDonnell, L.A.; Balog, C.I.; Bossers, K.; Deelder, A.M.; Swaab, D.F.; Verhaagen, J.; Mayboroda, O.A. A novel peptidomics approach to detect markers of Alzheimer's disease in cerebrospinal fluid. Methods 2012, 56, 500-507. [CrossRef]

39. Wildsmith, K.R.; Schauer, S.P.; Smith, A.M.; Arnott, D.; Zhu, Y.; Haznedar, J.; Kaur, S.; Mathews, W.R.; Honigberg, L.A. Identification of longitudinally dynamic biomarkers in Alzheimer's disease cerebrospinal fluid by targeted proteomics. Mol. Neurodegener. 2014, 9, 22. [CrossRef]

40. Korecka, M.; Shaw, L.M. Mass spectrometry-based methods for robust measurement of Alzheimer's Disease biomarkers in biological fluids. J. Neurochem. 2021. [CrossRef]

41. Rahimi, J.; Woehrer, A. Overview of cerebrospinal fluid cytology. In Neuropathology; Kovacs, G., Alafuzoff, I., Eds.; Elsevier: Amsterdam, The Netherlands, 2018; pp. 563-571. [CrossRef]

42. Guo, T.; Zhang, D.; Zeng, Y.; Huang, T.Y.; Xu, H.; Zhao, Y. Molecular and cellular mechanisms underlying the pathogenesis of Alzheimer's disease. Mol. Neurodegener. 2020, 15, 40. [CrossRef]

43. Reiber, H. Dynamics of brain-derived proteins in cerebrospinal fluid. Clin. Chim. Acta 2001, 310, 173-186. [CrossRef]

44. Stock, A.J.; Kasus-Jacobi, A.; Pereira, H.A. The role of neutrophil granule proteins in neuroinflammation and Alzheimer's disease. J. Neuroinflamm. 2018, 15, 240. [CrossRef] [PubMed]

45. Talib, L.L. Platelet biomarkers in Alzheimer's disease. World J. Psychiatry 2012, 2, 95. [CrossRef]

46. Arai, K.; Gowert, N.S.; Donner, L.; Chatterjee, M.; Eisele, Y.S.; Towhid, S.T.; Münzer, P.; Walker, B.; Ogorek, I.; Borst, O.; et al. Blood Platelets in the Progression of Alzheimer's Disease. PLoS ONE 2014, 9, e0090523. [CrossRef]

47. An, K.; Klyubin, I.; Kim, Y.; Jung, J.; Mably, A.J.; O’Dowd, S.T.; Lynch, T.; Kanmert, D.; Lemere, C.A.; Finan, G.M.; et al. Exosomes neutralize synaptic-plasticity-disrupting activity of $A \beta$ assemblies in vivo. Mol. Brain 2013, 6, 47. [CrossRef]

48. Li, M.; Huang, L.; Chen, J.; Ni, F.; Zhang, Y.; Liu, F. Isolation of Exosome Nanoparticles from Human Cerebrospinal Fluid for Proteomic Analysis. ACS Appl. Nano Mater. 2021, 4, 3351-3359. [CrossRef]

49. Zahra, K.; Dey, T.; Ashish; Mishra, S.P.; Pandey, U. Pyruvate Kinase M2 and Cancer: The Role of PKM2 in Promoting Tumorigenesis. Front. Oncol. 2020, 10, 159. [CrossRef]

50. Bell, S.M.; Burgess, T.; Lee, J.; Blackburn, D.J.; Allen, S.P.; Mortiboys, H. Peripheral Glycolysis in Neurodegenerative Diseases. Int. J. Mol. Sci. 2020, 21, 8924. [CrossRef]

51. Le Douce, J.; Maugard, M.; Veran, J.; Matos, M.; Jégo, P.; Vigneron, P.-A.; Faivre, E.; Toussay, X.; Vandenberghe, M.; Balbastre, Y.; et al. Impairment of Glycolysis-Derived 1-Serine Production in Astrocytes Contributes to Cognitive Deficits in Alzheimer's Disease. Cell Metab. 2020, 31, 503-517.e508. [CrossRef] [PubMed]

52. Bigl, M.; Bruckner, M.K.; Arendt, T.; Bigl, V.; Eschrich, K. Activities of key glycolytic enzymes in the brains of patients with Alzheimer's disease. J. Neural. Transm. 1999, 106, 499-511. [CrossRef]

53. Goodman, A.B.; Pardee, A.B. Evidence for defective retinoid transport and function in late onset Alzheimer's disease. Proc. Natl. Acad. Sci. USA 2003, 100, 2901-2905. [CrossRef] 
54. Ray, S.; Das, B.; Dasgupta, S. Potential therapeutic roles of retinoids for prevention of neuroinflammation and neurodegeneration in Alzheimer's disease. Neural Regen. Res. 2019, 14, 1880. [CrossRef]

55. Kölsch, H.; Lütjohann, D.; Jessen, F.; Popp, J.; Hentschel, F.; Kelemen, P.; Friedrichs, S.; Maier, T.A.W.; Heun, R. RXRA gene variations influence Alzheimer's disease risk and cholesterol metabolism. J. Cell. Mol. Med. 2009, 13, 589-598. [CrossRef]

56. Xiong, H.; Callaghan, D.; Jones, A.; Walker, D.G.; Lue, L.-F.; Beach, T.G.; Sue, L.I.; Woulfe, J.; Xu, H.; Stanimirovic, D.B.; et al. Cholesterol retention in Alzheimer's brain is responsible for high $\beta$ - and $\gamma$-secretase activities and A $\beta$ production. Neurobiol. Dis. 2008, 29, 422-437. [CrossRef] [PubMed]

57. Ojo, J.O.; Crynen, G.; Reed, J.M.; Ajoy, R.; Vallabhaneni, P.; Algamal, M.; Leary, P.; Rafi, N.G.; Mouzon, B.; Mullan, M.; et al. Unbiased Proteomic Approach Identifies Unique and Coincidental Plasma Biomarkers in Repetitive mTBI and AD Pathogenesis. Front. Aging Neurosci. 2018, 10, 405. [CrossRef] [PubMed]

58. Sodhi, R.K.; Singh, N. Retinoids as potential targets for Alzheimer's disease. Pharmacol. Biochem. Behav. 2014, 120, 117-123. [CrossRef] [PubMed]

59. Obulesu, M.; Dowlathabad, M.R.; Bramhachari, P.V. Carotenoids and Alzheimer's Disease: An insight into therapeutic role of retinoids in animal models. Neurochem. Int. 2011, 59, 535-541. [CrossRef] [PubMed]

60. Fitz, N.F.; Nam, K.N.; Koldamova, R.; Lefterov, I. Therapeutic targeting of nuclear receptors, liver X and retinoid X receptors, for Alzheimer's disease. Br. J. Pharmacol. 2019, 176, 3599-3610. [CrossRef] [PubMed]

61. Terwel, D.; Steffensen, K.R.; Verghese, P.B.; Kummer, M.P.; Gustafsson, J.A.; Holtzman, D.M.; Heneka, M.T. Critical Role of Astroglial Apolipoprotein E and Liver X Receptor- Expression for Microglial A Phagocytosis. J. Neurosci. 2011, 31, 7049-7059. [CrossRef] [PubMed]

62. Zelcer, N.; Khanlou, N.; Clare, R.; Jiang, Q.; Reed-Geaghan, E.G.; Landreth, G.E.; Vinters, H.V.; Tontonoz, P. Attenuation of neuroinflammation and Alzheimer's disease pathology by liver x receptors. Proc. Natl. Acad. Sci. USA 2007, 104, 10601-10606. [CrossRef]

63. Andersson, S.; Gustafsson, N.; Warner, M.; Gustafsson, J.A. Inactivation of liver X receptor leads to adult-onset motor neuron degeneration in male mice. Proc. Natl. Acad. Sci. USA 2005, 102, 3857-3862. [CrossRef]

64. Zelcer, N. Liver $X$ receptors as integrators of metabolic and inflammatory signaling. J. Clin. Investig. 2006, 116, 607-614. [CrossRef] [PubMed]

65. Dominiczak, M.H.; Caslake, M.J. Apolipoproteins: Metabolic role and clinical biochemistry applications. Ann. Clin. Biochem. Int. J. Lab. Med. 2011, 48, 498-515. [CrossRef]

66. Paula-Lima, A.C.; Tricerri, M.A.; Brito-Moreira, J.; Bomfim, T.R.; Oliveira, F.F.; Magdesian, M.H.; Grinberg, L.T.; Panizzutti, R.; Ferreira, S.T. Human apolipoprotein A-I binds amyloid- $\beta$ and prevents A $\beta$-induced neurotoxicity. Int. J. Biochem. Cell Biol. 2009, 41, 1361-1370. [CrossRef] [PubMed]

67. Schellenberg, G.; Bird, T.; Wijsman, E.; Orr, H.; Anderson, L.; Nemens, E.; White, J.; Bonnycastle, L.; Weber, J.; Alonso, M.; et al. Genetic linkage evidence for a familial Alzheimer's disease locus on chromosome 14. Science 1992, 258, 668-671. [CrossRef]

68. Friedman, D.J.; Pollak, M.R. APOL1and Kidney Disease: From Genetics to Biology. Annu. Rev. Physiol. 2020, 82, 323-342. [CrossRef]

69. Cohen-Cory, S. The developing synapse: Construction and modulation of synaptic structures and circuits. Science 2002, 298, 770-776. [CrossRef] [PubMed]

70. Masliah, E.; Mallory, M.; Alford, M.; DeTeresa, R.; Hansen, L.A.; McKeel, D.W.; Morris, J.C. Altered expression of synaptic proteins occurs early during progression of Alzheimer's disease. Neurology 2001, 56, 127-129. [CrossRef] [PubMed]

71. Selkoe, D.J. Alzheimer's Disease Is a Synaptic Failure. Science 2002, 298, 789-791. [CrossRef] [PubMed]

72. Boles, N.C.; Hirsch, S.E.; Le, S.; Corneo, B.; Najm, F.; Minotti, A.P.; Wang, Q.; Lotz, S.; Tesar, P.J.; Fasano, C.A. NPTX1 Regulates Neural Lineage Specification from Human Pluripotent Stem Cells. Cell Rep. 2014, 6, 724-736. [CrossRef] [PubMed]

73. Sia, G.-M.; Béïque, J.-C.; Rumbaugh, G.; Cho, R.; Worley, P.F.; Huganir, R.L. Interaction of the N-Terminal Domain of the AMPA Receptor GluR4 Subunit with the Neuronal Pentraxin NP1 Mediates GluR4 Synaptic Recruitment. Neuron 2007, 55, 87-102. [CrossRef]

74. Cummings, D.M.; Benway, T.A.; Ho, H.; Tedoldi, A.; Fernandes Freitas, M.M.; Shahab, L.; Murray, C.E.; Richard-Loendt, A.; Brandner, S.; Lashley, T.; et al. Neuronal and Peripheral Pentraxins Modify Glutamate Release and may Interact in Blood-Brain Barrier Failure. Cereb. Cortex 2017, 27, 3437-3448. [CrossRef] [PubMed]

75. Lee, S.-J.; Wei, M.; Zhang, C.; Maxeiner, S.; Pak, C.; Calado Botelho, S.; Trotter, J.; Sterky, F.H.; Südhof, T.C. Presynaptic Neuronal Pentraxin Receptor Organizes Excitatory and Inhibitory Synapses. J. Neurosci. 2017, 37, 1062-1080. [CrossRef] [PubMed]

76. Wang, Z.; Wang, X.; Zou, H.; Dai, Z.; Feng, S.; Zhang, M.; Xiao, G.; Liu, Z.; Cheng, Q. The Basic Characteristics of the Pentraxin Family and Their Functions in Tumor Progression. Front. Immunol. 2020, 11, 1757. [CrossRef] [PubMed]

77. Yue, W.; Wang, T.; Zachariah, E.; Lin, Y.; Yang, C.S.; Xu, Q.; DiPaola, R.S.; Tan, X.-L. Transcriptomic analysis of pancreatic cancer cells in response to metformin and aspirin: An implication of synergy. Sci. Rep. 2015, 5, 1-11. [CrossRef]

78. Karagkounis, G.; Thai, L.; DeVecchio, J.; Gantt, G.A.; Duraes, L.; Pai, R.K.; Kalady, M.F. NPTX2 is associated with neoadjuvant therapy response in rectal cancer. J. Surg. Res. 2016, 202, 112-117. [CrossRef]

79. Lee, G.W.; Lee, T.H.; Vilcek, J. TSG-14, a tumor necrosis factor- and IL-1-inducible protein, is a novel member of the pentaxin family of acute phase proteins. J. Immunol. 1993, 150, 1804-1812. 
80. Xiao, M.-F.; Xu, D.; Craig, M.T.; Pelkey, K.A.; Chien, C.-C.; Shi, Y.; Zhang, J.; Resnick, S.; Pletnikova, O.; Salmon, D.; et al. NPTX2 and cognitive dysfunction in Alzheimer's Disease. eLife 2017, 6, e23798. [CrossRef]

81. De Groot, J.; Sontheimer, H. Glutamate and the biology of gliomas. Glia 2011, 59, 1181-1189. [CrossRef]

82. Radin, D.P.; Patel, P. A current perspective on the oncopreventive and oncolytic properties of selective serotonin reuptake inhibitors. Biomed. Pharmacother. 2017, 87, 636-639. [CrossRef]

83. Abad, M.A.; Enguita, M.; DeGregorio-Rocasolano, N.; Ferrer, I.; Trullas, R. Neuronal Pentraxin 1 Contributes to the Neuronal Damage Evoked by Amyloid- and Is Overexpressed in Dystrophic Neurites in Alzheimer's Brain. J. Neurosci. 2006, 26, 12735-12747. [CrossRef] [PubMed]

84. Brito-Moreira, J.; Lourenco, M.V.; Oliveira, M.M.; Ribeiro, F.C.; Ledo, J.H.; Diniz, L.P.; Vital, J.F.S.; Magdesian, M.H.; Melo, H.M.; Barros-Aragão, F; et al. Interaction of amyloid- $\beta(\mathrm{A} \beta)$ oligomers with neurexin $2 \alpha$ and neuroligin 1 mediates synapse damage and memory loss in mice. J. Biol. Chem. 2017, 292, 7327-7337. [CrossRef] [PubMed]

85. Pettem, K.L.; Yokomaku, D.; Luo, L.; Linhoff, M.W.; Prasad, T.; Connor, S.A.; Siddiqui, T.J.; Kawabe, H.; Chen, F.; Zhang, L.; et al. The Specific $\alpha$-Neurexin Interactor Calsyntenin-3 Promotes Excitatory and Inhibitory Synapse Development. Neuron 2013, 80, 113-128. [CrossRef] [PubMed]

86. Um, J.W.; Pramanik, G.; Ko, J.S.; Song, M.Y.; Lee, D.; Kim, H.; Park, K.S.; Südhof, T.C.; Tabuchi, K.; Ko, J. Calsyntenins Function as Synaptogenic Adhesion Molecules in Concert with Neurexins. Cell Rep. 2014, 6, 1096-1109. [CrossRef] [PubMed]

87. Hintsch, G. The Calsyntenins-A Family of Postsynaptic Membrane Proteins with Distinct Neuronal Expression Patterns. Mol. Cell. Neurosci. 2002, 21, 393-409. [CrossRef]

88. Uchida, Y.; Gomi, F. The role of calsyntenin-3 in dystrophic neurite formation in Alzheimer's disease brain. Geriatr. Gerontol. Int. 2016, 16, 43-50. [CrossRef]

89. Pilozzi, A.; Carro, C.; Whalen, M.; Huang, X. Blood-Brain Barrier Degradation and the Implication of SPARC Protein as a Potential Therapeutic Target for Alzheimer's Disease. In Alzheimer's Disease: Drug Discovery; Huang, X., Ed.; Exon Publications: Brisbane, Australia, 2020. [CrossRef]

90. McCurdy, S.; Baicu, C.F.; Heymans, S.; Bradshaw, A.D. Cardiac extracellular matrix remodeling: Fibrillar collagens and Secreted Protein Acidic and Rich in Cysteine (SPARC). J. Mol. Cell. Cardiol. 2010, 48, 544-549. [CrossRef]

91. Giannoni, P.; Arango-Lievano, M.; Neves, I.D.; Rousset, M.-C.; Baranger, K.; Rivera, S.; Jeanneteau, F.; Claeysen, S.; Marchi, N. Cerebrovascular pathology during the progression of experimental Alzheimer's disease. Neurobiol. Dis. 2016, 88, 107-117. [CrossRef] [PubMed]

92. Awwad, K.; Hu, J.; Shi, L.; Mangels, N.; Abdel Malik, R.; Zippel, N.; Fisslthaler, B.; Eble, J.A.; Pfeilschifter, J.; Popp, R.; et al. Role of secreted modular calcium-binding protein 1 (SMOC1) in transforming growth factor $\beta$ signalling and angiogenesis. Cardiovasc. Res. 2015, 106, 284-294. [CrossRef] [PubMed]

93. Bai, B.; Wang, X.; Li, Y.; Chen, P.-C.; Yu, K.; Dey, K.K.; Yarbro, J.M.; Han, X.; Lutz, B.M.; Rao, S.; et al. Deep Multilayer Brain Proteomics Identifies Molecular Networks in Alzheimer's Disease Progression. Neuron 2020, 105, 975-991.e977. [CrossRef]

94. Sathe, G.; Albert, M.; Darrow, J.; Saito, A.; Troncoso, J.; Pandey, A.; Moghekar, A. Quantitative proteomic analysis of the frontal cortex in Alzheimer's disease. J. Neurochem. 2020, 156, 988-1002. [CrossRef]

95. Barrera-Ocampo, A.; Arlt, S.; Matschke, J.; Hartmann, U.; Puig, B.; Ferrer, I.; Zürbig, P.; Glatzel, M.; Sepulveda-Falla, D.; Jahn, H. Amyloid- $\beta$ Precursor Protein Modulates the Sorting of Testican-1 and Contributes to Its Accumulation in Brain Tissue and Cerebrospinal Fluid from Patients with Alzheimer Disease. J. Neuropathol. Exp. Neurol. 2016, 75, 903-916. [CrossRef]

96. Schechter, I.; Ziv, E. Cathepsins S, B and L with aminopeptidases display beta-secretase activity associated with the pathogenesis of Alzheimer's disease. Biol. Chem. 2011, 392, 555-569. [CrossRef]

97. Merlo, S.; Sortino, M.A. Estrogen activates matrix metalloproteinases-2 and -9 to increase beta amyloid degradation. Mol. Cell. Neurosci. 2012, 49, 423-429. [CrossRef]

98. Ichimura, T.; Isobe, T.; Okuyama, T.; Yamauchi, T.; Fujisawa, H. Brain 14-3-3 protein is an activator protein that activates tryptophan 5-monooxygenase and tyrosine 3-monooxygenase in the presence of $\mathrm{Ca} 2+$,calmodulin-dependent protein kinase II. FEBS Lett. 1987, 219, 79-82. [CrossRef]

99. Cho, E.; Park, J.-Y. Emerging roles of 14-3-3 $\gamma$ in the brain disorder. BMB Rep. 2020, 53, 500-511. [CrossRef]

100. Cornell, B.; Toyo-oka, K. 14-3-3 Proteins in Brain Development: Neurogenesis, Neuronal Migration and Neuromorphogenesis. Front. Mol. Neurosci. 2017, 10, 318. [CrossRef]

101. Foote, M.; Zhou, Y. 14-3-3 proteins in neurological disorders. Int. J. Biochem. Mol. Biol. 2012, 3, $152-164$.

102. Kelly, J.; Moyeed, R.; Carroll, C.; Albani, D.; Li, X. Gene expression meta-analysis of Parkinson's disease and its relationship with Alzheimer's disease. Mol. Brain 2019, 12,1-10. [CrossRef]

103. Bartolomucci, A.; Pasinetti, G.M.; Salton, S.R.J. Granins as disease-biomarkers: Translational potential for psychiatric and neurological disorders. Neuroscience 2010, 170, 289-297. [CrossRef]

104. Bartolomucci, A.; Possenti, R.; Mahata, S.K.; Fischer-Colbrie, R.; Loh, Y.P.; Salton, S.R.J. The Extended Granin Family: Structure, Function, and Biomedical Implications. Endocr. Rev. 2011, 32, 755-797. [CrossRef] [PubMed]

105. Serby, M.; Richardson, S.B.; Twente, S.; Siekierski, J.; Corwin, J.; Rotrosen, J. CSF somatostatin in Alzheimer's disease. Neurobiol. Aging 1984, 5, 187-189. [CrossRef]

106. Sagar, S.M.; Flint Beal, M.; Marshall, P.E.; Landis, D.M.D.; Martin, J.B. Implications of neuropeptides in neurological diseases. Peptides 1984, 5, 255-262. [CrossRef] 
107. Paik, S.; Somvanshi, R.K.; Kumar, U. Somatostatin-Mediated Changes in Microtubule-Associated Proteins and Retinoic AcidInduced Neurite Outgrowth in SH-SY5Y Cells. J. Mol. Neurosci. 2019, 68, 120-134. [CrossRef]

108. Sodhi, C.P.; Phadke, S.A.; Batlle, D.; Sahai, A. Hypoxia Stimulates Osteopontin Expression and Proliferation of Cultured Vascular Smooth Muscle Cells. Diabetes 2001, 50, 1482-1490. [CrossRef]

109. Rabenstein, M.; Vay, S.U.; Flitsch, L.J.; Fink, G.R.; Schroeter, M.; Rueger, M.A. Osteopontin directly modulates cytokine expression of primary microglia and increases their survival. J. Neuroimmunol. 2016, 299, 130-138. [CrossRef]

110. Wung, J.; Perry, G.; Kowalski, A.; Harris, P.R.; Bishop, G.; Trivedi, M.; Johnson, S.; Smith, M.; Denhardt, D.; Atwood, C. Increased Expression of the Remodeling- and Tumorigenic-Associated Factor Osteopontin in Pyramidal Neurons of the Alzheimers Disease Brain. Curr. Alzheimer Res. 2007, 4, 67-72. [CrossRef] [PubMed]

111. Comi, C.; Carecchio, M.; Chiocchetti, A.; Nicola, S.; Galimberti, D.; Fenoglio, C.; Cappellano, G.; Monaco, F.; Scarpini, E.; Dianzani, U. Osteopontin is Increased in the Cerebrospinal Fluid of Patients with Alzheimer's Disease and Its Levels Correlate with Cognitive Decline. J. Alzheimer's Dis. 2010, 19, 1143-1148. [CrossRef] [PubMed]

112. Sensi, S.L.; Granzotto, A.; Siotto, M.; Squitti, R. Copper and Zinc Dysregulation in Alzheimer's Disease. Trends. Pharmacol. Sci. 2018, 39, 1049-1063. [CrossRef]

113. Mold, M.; Ouro-Gnao, L.; Wieckowski, B.M.; Exley, C. Copper prevents amyloid- $\beta 1-42$ from forming amyloid fibrils under near-physiological conditions in vitro. Sci. Rep. 2013, 3, 1256. [CrossRef]

114. Singh, I.; Sagare, A.P.; Coma, M.; Perlmutter, D.; Gelein, R.; Bell, R.D.; Deane, R.J.; Zhong, E.; Parisi, M.; Ciszewski, J.; et al. Low levels of copper disrupt brain amyloid- $\beta$ homeostasis by altering its production and clearance. Proc. Natl. Acad. Sci. USA 2013, 110, 14771-14776. [CrossRef]

115. Bagheri, S.; Squitti, R.; Haertlé, T.; Siotto, M.; Saboury, A.A. Role of Copper in the Onset of Alzheimer's Disease Compared to Other Metals. Front. Aging Neurosci. 2018, 9, 446. [CrossRef] [PubMed]

116. Roberts, B.R.; Ryan, T.M.; Bush, A.I.; Masters, C.L.; Duce, J.A. The role of metallobiology and amyloid-beta peptides in Alzheimer's disease. J. Neurochem. 2012, 120 (Suppl. 1), 149-166. [CrossRef] [PubMed]

117. Twomey, P.J.; Viljoen, A.; House, I.M.; Reynolds, T.M.; Wierzbicki, A.S. Relationship between serum copper, ceruloplasmin, and non-ceruloplasmin-bound copper in routine clinical practice. Clin. Chem. 2005, 51, 1558-1559. [CrossRef]

118. Vašák, M.; Meloni, G. Mammalian Metallothionein-3: New Functional and Structural Insights. Int. J. Mol. Sci. 2017, 18, 1117. [CrossRef]

119. Eipper, B.A.; Mains, R.E. Peptide $\alpha$-Amidation. Annu. Rev. Physiol. 1988, 50, 333-344. [CrossRef]

120. Eipper, B.A.; Stoffers, D.A.; Mains, R.E. The biosynthesis of neuropeptides: Peptide alpha-amidation. Annu. Rev. Neurosci. 1992, 15, 57-85. [CrossRef]

121. Wand, G.S.; May, C.; May, V.; Whitehouse, P.J.; Rapoport, S.I.; Eipper, B.A. Alzheimer's disease: Low levels of peptide alphaamidation activity in brain and CSF. Neurology 1987, 37, 1057-1061. [CrossRef]

122. Miners, J.S.; Clarke, P.; Love, S. Clusterin levels are increased in Alzheimer's disease and influence the regional distribution of A $\beta$. Brain Pathol. 2017, 27, 305-313. [CrossRef]

123. Thambisetty, M.; Simmons, A.; Velayudhan, L.; Hye, A.; Campbell, J.; Zhang, Y.; Wahlund, L.-O.; Westman, E.; Kinsey, A.; Güntert, A.; et al. Association of Plasma Clusterin Concentration With Severity, Pathology, and Progression in Alzheimer Disease. Arch. Gen. Psychiatry 2010, 67, 739-748. [CrossRef] [PubMed]

124. Hsieh, C.L.; Koike, M.; Spusta, S.C.; Niemi, E.C.; Yenari, M.; Nakamura, M.C.; Seaman, W.E. A role for TREM2 ligands in the phagocytosis of apoptotic neuronal cells by microglia. J. Neurochem. 2009, 109, 1144-1156. [CrossRef]

125. Zhao, Y.; Wu, X.; Li, X.; Jiang, L.-L.; Gui, X.; Liu, Y.; Sun, Y.; Zhu, B.; Piña-Crespo, J.C.; Zhang, M.; et al. TREM2 Is a Receptor for $\beta$-Amyloid that Mediates Microglial Function. Neuron 2018, 97, 1023-1031.e1027. [CrossRef]

126. Guerreiro, R.; Wojtas, A.; Bras, J.; Carrasquillo, M.; Rogaeva, E.; Majounie, E.; Cruchaga, C.; Sassi, C.; Kauwe, J.S.K.; Younkin, S.; et al. TREM2 Variants in Alzheimer's Disease. N. Engl. J. Med. 2013, 368, 117-127. [CrossRef]

127. Jonsson, T.; Stefansson, H.; Steinberg, S.; Jonsdottir, I.; Jonsson, P.V.; Snaedal, J.; Bjornsson, S.; Huttenlocher, J.; Levey, A.I.; Lah, J.J.; et al. Variant of TREM2 Associated with the Risk of Alzheimer's Disease. N. Engl. J. Med. 2013, 368, 107-116. [CrossRef] [PubMed]

128. Giraldo, M.; Lopera, F.; Siniard, A.L.; Corneveaux, J.J.; Schrauwen, I.; Carvajal, J.; Muñoz, C.; Ramirez-Restrepo, M.; Gaiteri, C.; Myers, A.J.; et al. Variants in triggering receptor expressed on myeloid cells 2 are associated with both behavioral variant frontotemporal lobar degeneration and Alzheimer's disease. Neurobiol. Aging 2013, 34, 2077.e2011-2077.e2018. [CrossRef]

129. Koike, H.; Seki, H.; Kouchi, Z.; Ito, M.; Kinouchi, T.; Tomioka, S.; Sorimachi, H.; Saido, T.C.; Maruyama, K.; Suzuki, K.; et al. Thimet Oligopeptidase Cleaves the Full-Length Alzheimer Amyloid Precursor Protein at a $\beta$-Secretase Cleavage Site in COS Cells. J. Biochem. 1999, 126, 235-242. [CrossRef] [PubMed]

130. Yamin, R.; Malgeri, E.G.; Sloane, J.A.; McGraw, W.T.; Abraham, C.R. Metalloendopeptidase EC 3.4.24.15 Is Necessary for Alzheimer's Amyloid- $\beta$ Peptide Degradation. J. Biol. Chem. 1999, 274, 18777-18784. [CrossRef]

131. Pollio, G.; Hoozemans, J.J.M.; Andersen, C.A.; Roncarati, R.; Rosi, M.C.; van Haastert, E.S.; Seredenina, T.; Diamanti, D.; Gotta, S.; Fiorentini, A.; et al. Increased expression of the oligopeptidase THOP1 is a neuroprotective response to A $\beta$ toxicity. Neurobiol. Dis. 2008, 31, 145-158. [CrossRef] 
132. Choi, J.; Levey, A.I.; Weintraub, S.T.; Rees, H.D.; Gearing, M.; Chin, L.-S.; Li, L. Oxidative Modifications and Down-regulation of Ubiquitin Carboxyl-terminal Hydrolase L1 Associated with Idiopathic Parkinson's and Alzheimer's Diseases. J. Biol. Chem. 2004, 279, 13256-13264. [CrossRef]

133. Sultana, R.; Boyd-Kimball, D.; Cai, J.; Pierce, W.M.; Klein, J.B.; Merchant, M.; Butterfield, D.A.; Boldyrev, A.; Johnson, P. Proteomics Analysis of the Alzheimer's Disease Hippocampal Proteome. J. Alzheimer's Dis. 2007, 11, 153-164. [CrossRef] [PubMed]

134. Öhrfelt, A.; Johansson, P.; Wallin, A.; Andreasson, U.; Zetterberg, H.; Blennow, K.; Svensson, J. Increased Cerebrospinal Fluid Levels of Ubiquitin Carboxyl-Terminal Hydrolase L1 in Patients with Alzheimer's Disease. Dement. Geriatr. Cogn. Disord. Extra 2016, 6, 283-294. [CrossRef] [PubMed]

135. Wein, A.N.; McMaster, S.R.; Takamura, S.; Dunbar, P.R.; Cartwright, E.K.; Hayward, S.L.; McManus, D.T.; Shimaoka, T.; Ueha, S.; Tsukui, T.; et al. CXCR6 regulates localization of tissue-resident memory CD8 T cells to the airways. J. Exp. Med. 2019, 216, 2748-2762. [CrossRef] [PubMed]

136. Veinotte, L.; Gebremeskel, S.; Johnston, B. CXCL16-positive dendritic cells enhance invariant natural killer T cell-dependent IFN $\gamma$ production and tumor control. OncoImmunology 2016, 5, e1160979. [CrossRef]

137. Jadidi-Niaragh, F.; Shegarfi, H.; Naddafi, F.; Mirshafiey, A. The Role of Natural Killer Cells in Alzheimer's Disease. Scand. J. Immunol. 2012, 76, 451-456. [CrossRef]

138. Anggono, V.; Koç-Schmitz, Y.; Widagdo, J.; Kormann, J.; Quan, A.; Chen, C.-M.; Robinson, P.J.; Choi, S.-Y.; Linden, D.J.; Plomann, M.; et al. PICK1 interacts with PACSIN to regulate AMPA receptor internalization and cerebellar long-term depression. Proc. Natl. Acad. Sci. USA 2013, 110, 13976-13981. [CrossRef] [PubMed]

139. Clayton, E.L.; Anggono, V.; Smillie, K.J.; Chau, N.; Robinson, P.J.; Cousin, M.A. The Phospho-Dependent Dynamin-Syndapin Interaction Triggers Activity-Dependent Bulk Endocytosis of Synaptic Vesicles. J. Neurosci. 2009, 29, 7706-7717. [CrossRef]

140. Modregger, J. PACSIN 1 interacts with huntingtin and is absent from synaptic varicosities in presymptomatic Huntington's disease brains. Hum. Mol. Genet. 2002, 11, 2547-2558. [CrossRef]

141. Takano, M.; Yamashita, T.; Nagano, K.; Otani, M.; Maekura, K.; Kamada, H.; Tsunoda, S.-i.; Tsutsumi, Y.; Tomiyama, T.; Mori, H.; et al. Proteomic analysis of the hippocampus in Alzheimer's disease model mice by using two-dimensional fluorescence difference in gel electrophoresis. Neurosci. Lett. 2013, 534, 85-89. [CrossRef]

142. Zhao, X.; Yao, H.; Li, X. Unearthing of Key Genes Driving the Pathogenesis of Alzheimer's Disease via Bioinformatics. Front. Genet. 2021, 12, 641100. [CrossRef] [PubMed]

143. Salih, D.A.; Bayram, S.; Guelfi, S.; Reynolds, R.H.; Shoai, M.; Ryten, M.; Brenton, J.W.; Zhang, D.; Matarin, M.; Botia, J.A.; et al. Genetic variability in response to amyloid beta deposition influences Alzheimer's disease risk. Brain Commun. 2019, 1, fcz022. [CrossRef] [PubMed]

144. Trovò, L.; Ahmed, T.; Callaerts-Vegh, Z.; Buzzi, A.; Bagni, C.; Chuah, M.; VandenDriessche, T.; D’Hooge, R.; Balschun, D.; Dotti, C.G. Low hippocampal PI(4,5)P2 contributes to reduced cognition in old mice as a result of loss of MARCKS. Nat. Neurosci. 2013, 16, 449-455. [CrossRef] [PubMed] 